\title{
School Counseling Services Information System Optimization in Multi-Level School at Surabaya
}

\author{
Susana Limanto*, Andre*, Dhiani Tresna Absari, Sholeh Hadi Setyawan \\ Informatics Engineering Department, University of Surabaya, Surabaya 60293, East Java, Indonesia \\ Raya Kalirungkut 60293, Surabaya, East Java, Indonesia. Phone : 62-031-2981395 \\ *Corresponding author Email:andrenoto@yahoo.co.id, susana@staff.ubaya.ac.id
}

Received: 30 August 2016 Accepted: 30 May 2017

The success criteria of formal education of a student are not only determined by academic ability, but also by attitude, interest, and value that is possessed by the student. Therefore, the School Counseling Services (SCS) becomes more important part of the school, to help students to accept and understand themselves and their environments. The SCS can also drive the students to self-direct and self-adapt to the demands of their environments. By providing a good service, SCS can help students to study and reach better achievement in education, social, and their career related to their interest and their talent. The goal of this research is to develop a software to optimize process of SCS used in multi-level school at Surabaya. Software is developed based on analysis and grand design from previous research. Evaluation of Information System SCS conducted by distributing survey to all three types of users, which are: Classroom Teacher, Counseling Services Teacher, and parents. The evaluation results proves that at least $75 \%$ of users agreed that the SCS able to improve teacher performances, improve capability of collaboration, each user understand its each individual roles, and maintain communication between different users. Furthermore, SCS IS could be expanded for more better and optimum service solution. Notification and messaging system between student-parents-teacher could be added to improve integrity of system, and to minimize redundancy. Academic System and other system such as School Medical Facilities should be interconnected to improve better services. Deployment planned to be carried out by executing the old and new systems simultaneously during academic year 2015-2016 in the scope of Kindergarten, Grade 1 and 4 Elementary School. Evaluation will be conducted after one year for further development.

Keywords: School Information System, Counseling Services.

\section{Introduction}

Children are the assets that essential for future generation of nation. In order to prepare future nation leader, children must be well educated. Education is important aspect that should be maintained and introduced since childhood. Children receive education through schools or families. The successfulness of education is not only determined by the ability to think, but also influenced by other factors, such as attitude and mental maturity. According to Bloom taxonomy indicated that the goals of education can be categorize into three domains: cognitive, affective and psychomotor ${ }^{1}$. Cognitive domain relates to the learner's knowledge and the development of intellectual abilities and skills ${ }^{1}$. The focus of the affective domain is on the learner's interest, 
attitudes, and values ${ }^{1}$. Psychomotor domain focuses on motor skills and is believed would not be useful $^{1}$.

Since the success of children development is not only determined by the cognitive abilities, but also the affective abilities, then the schools in Indonesia provide facilities that support children (student) education which is named: School Counseling Services (SCS). According to the Encyclopedia of Educational Psychology, school counseling is a comprehensive program that facilitates students' academic, career, and personal/ social development within the school setting $^{2,3}$. School counseling can help to advance and enrich the overall goal of education, to enable the individual to lead a balanced and successful life ${ }^{4}$. In Indonesia, the SCS is included in the educational unit level curriculum, as a part of "self development" curriculum ${ }^{5}$.

The history of school guidance program started from the late of $1800 \mathrm{~s}^{6}$. The role of the school counselors became more important as schools move forward into the twenty first century $^{7,8}$. A recent study states that the proper implementation of the guidance and counseling services in schools can only be effective, if all stakeholders can properly play their roles in the implementation process. A good collaboration and communication is needed ${ }^{9}$. Therefore, the school counselors should work together with students, parents, teachers, administrators, and other members of the community to build a supportive learning environment that nurtures the development of academic, career, and personal/social competence among students ${ }^{10,11,12}$. The SCS becomes more trusted by the parents, in a stronger and more respected acceptance of the contribution of the SCS to student's achievement and success in school ${ }^{13}$. For the children of 1014 year ages, the role of the SCS is very important, because they experience more anxiety than their elementary or high school counterparts ${ }^{14}$.

The school counselors together with the academic advisors should monitor the students' development progress. Counseling and problem solving mainly becomes the task of the academic advisors. If the academic advisors could not handle, the problem will be escalated to be solved by the school counselors. To recognize and understand more about the students' development progress, the teachers probably should act as the students' best friends. This closer relationship can help to improve the information depth and the openness of the students to the communication, therefore can help the SCS to detect any problems earlier and easier to solve.

Most of the students' time is at home, therefore any treatment or improvement designed by the SCS to a student won't yield maximum result without the participation of the parents ${ }^{15}$. The cooperation between parents and the SCS is very important to enhance the goal of creating a good environment for the students to reach their best achievements ${ }^{16}$. That cooperation needs good and active communication between two parties, especially to coordinate and unify the strategies of the treatment or improvement to the students.

The communication technologies nowadays including internet, enable people to get information from many resources easily, fast and cheap. The number of Internet users in Indonesia was 63 million in 2012, and will be 167 million in 2015, according to the Indonesia Internet Service Provider Association ${ }^{17}$. The high rate of the Internet technology penetration in Indonesia becomes an important factor to support coordination between counselor, teacher, and the parents to get better counseling services. The Internet technology combined by the development of smart phones / mobile devices may be utilized to establish a fast, easy and cheap communication channel between two parties. The key design challenge is how to make such 
devices usable and affordable to a heterogeneous set of users ${ }^{18}$. The related researches in this area are for example "Guidance and Counseling Application"" and "Guidance and Counseling Management Information System"20.

\section{Methodology}

Research conducted is classified as applied research, for the reason that research offer practical solution in educational institutions ${ }^{21}$. As for methodology used to perform this study is software development life cycle. This method offers structured and formal steps ${ }^{22}$. However, in order to adjust to complex needs of information technology conditions level which required great flexibility and responsiveness then the software development life cycle will be combined with action research approach because researchers will collaborate with practitioners from the world of education, especially from the education institute for early childhood, basic and intermediate in order to produce a work that is beneficial ${ }^{23,24}$. Collaboration with practitioners from the world-related education will greatly assist researchers in understanding the working practices in the field. The understanding of field work practices is very important to ensure the validity and completeness the needs of educational institutions which is the goal of this study.

Educational institutions that take part as the object of this research is a Al Azhar Kelapa Gading multi-level school, Surabaya. This school comprised of four levels: Azhar Park, kindergarten, elementary school and junior high school.

The research was initiated with the analysis and system design. This has been conducted on previous research and the results have been published. Results of the previous research used as reference for implementation. Implementation created in two versions: mobile and web version. The mobile version is intended for parents that accessible from anywhere, while the web version is more focused on school because it's related to administrative things. Implementation of data was made using MySQL version 5.5 and implementation of the program was conducted by using CodeIgniter PHP framework 2.0.

Once the implementation is completed, following testing is conducted to ensure that the creating program meets user needs. There are three testing used: unit testing, integration testing, and User Acceptance Testing (UAT). Unit testing conducted individually for each facility (process) that is in each of the modules. Integration testing is done to ensure that process are correct and in accordance with the desired specifications. Unit testing and integration testing performed using black box testing, i.e. by providing input and seeing the output generated. The result of unit testing and integration testing produced some minor errors and corrected afterward to set foundation for UAT preparation. Before UAT is conducted, the school staff trained using SCS IS and parents are informed about this program feature and services. UAT conducted by distributing questionnaires. The questionnaire distributed to all School Guidance and Counseling teacher. Distribution method for parent questionnaire is using simple random sampling.

Once all testing is done, the last phase is deployment. Deployment is done by implement simultaneously both manual and using SCS IS during 1 year period in kindergarten and elementary class. After one year, system will be evaluated for future development.

\section{Results and Discussion}


Preliminary Study has been done to analyze and design the SCS Information System. Two surveys were conducted in analyze step. The first survey was aimed to get the description of the current system, the problems that may occur during current system implementation and the expectation of improvement from the internal school institution ${ }^{25}$. The second survey was done by distributing questionnaires to the parents, in order to get the problems related to the SCS from the parents' view, the expectation of improvement and also the pattern of communication preferred by the parents to the SCS institution ${ }^{25}$.

Subsequently, the current problem expected to be solved here have been narrowed down to the need of communication media tools. This particular media tools grant the stakeholders (teachers, parents, students, school counselors, administration, and school managements) to communicate, coordinate, collaborate, and synchronize about strategies and goals for treating student and building supportive learning environment that nurtures the development of academic, career, and personal/social competence among students. Furthermore media tools should be able to generate routine report which usually takes time to compose and created by manual approach $^{25}$.

After carefully analyze the information taken from two surveys, the improvement and optimization of the current SCS was designed. The design had been validated to the SCS, teachers and school managements to make sure that the design meets the requirements both for operational and managerial purposes ${ }^{26}$. SCS information system program is made based on the design that has been validated and refined. The program is made in two versions: mobile version and the web version. The mobile version is intended for parents and students that accessible from anywhere, while the web version is more focused on school. Figure 1 shows an example of Student counseling history. Figure 2 shows an example of Daily Record Students' Case, and Figure 3 shows an example of home visit entry.

SCS is planned to be implemented on multi-level school on Surabaya, Indonesia. There are three steps to do to make sure everything working well: testing, socialize, and training. Testing is used to obtain information of the users in terms of the learning gap that fulfill the requirement standard of this application. There are three testing used: unit testing, integration testing, and User Acceptance Testing (UAT).Unit testing conducted individually for each facility (process) that exist in each of the modules. Integration testing is done to ensure that process are correct and in accordance with the desired specifications. The result of unit testing and integration testing produced some minor errors and corrected afterward to set foundation for UAT preparation. Before UAT is conducted, the school staff trained using SCS IS and parents are informed about this program feature and services. UAT is collected by distributing questionnaires to users with distribution scheme as shown in table 1. The questionnaire distributed to all School Guidance and Counseling teacher. Distribution method for parent questionnaire is using simple random sampling.

Around $75 \%$ of parents stated that the SCS IS succeed to provide service in term of maintaining communication between School Guidance and Counseling teacher regarding their children social, intellectual, and emotional development. Several suggestions mention that software could be developed with 1) smart notification system to alert parents about important information from the school; 2) monitor their child's academic results; 3) and encourage teacher to be more actively respond the message sent by the parents. 
About 86\% teacher agree that SCS IS succeed to provide better services for stakeholder (parents) and help teacher examine student development more clearly and understandably. However several feedbacks received after respondent finished UAT periods. Classroom teachers feel the need for dissemination to parents so they understand the discussion topic and time constraint when using the application.

Eighty-five percent of School Guidance and Counselor teacher agree with the facilities provided by SCS IS, however they hopes that the application could be integrated with the academic system and School Medical Unit. Therefore the academic, physical and health development data is maintained within single integrated system. Additionally, there are some suggestions given by the user, which is for the application could be linked with the SMS gateway so that if new information will automatically provide notification to parents mobile phone.

Once all testing is done, the last phase is deployment. Deployment is done by implement simultaneously both manual and using SCS IS during 1 year period in kindergarten and elementary class. Because the testing phase is completed in the middle of the school year 20152016, the deployment will start beginning of the school year 2016-2017. After one year, system will be evaluated for future development.

\section{Conclusion}

A good SCS can contribute to the success of achieving educational goals, since the SCS nurtures the development of academic, career, and personal/social competence among students. Proper implementation of the guidance and counseling services in schools can only be effective, if all stakeholders can properly play their roles in the implementation process. A good collaboration and communication is needed among all parties involved. The improvement in this area is done by adopted the electronic communication based on the Internet technology and mobile devices programming. Another optimization applied to the system by utilizing relational database system to record all of the SCS activities and create auto-generated reports based on the database. In order to further optimize the usage of SCS should be added notification facility for parents. Notification facility should be integrated within school system including Academic and also School Medical Unit.

\section{Acknowledgments}

The authors express gratitude to Direktorat Jenderal Pendidikan Tinggi Indonesia for the research grant, University of Surabaya, and Al Azhar Kelapa Gading Multilevel School Surabaya for all of the information and facilities that have been given.

\section{References and Notes}

1. Callister, Paul D. "Time to blossom: An inquiry into bloom's taxonomy as a hierarchy and means for teaching legal research skills." Law Libr. J. 102 (2010): 191.

2. American School Counselor Association. The ASCA National Model: A framework for school counseling programs (3rd. ed.). Alexandria, VA: American School Counseling Association (2012).

3. N. Salkind. Encyclopedia of Educational Psychology, California: SAGE Publications, Inc. (2008). 
4. Lozano. Accompanying Gulliver Personal Counseling in Secondary School Education, Psychology in Spain. (1997) 137-155.

5. Counseling Undana. The Importance of Student Counseling in School / out of School: The Importance of Student Counseling Program in Overall Education Program of Schools. [online] Available at <http://bimbingankonseling-undana.blogspot.com/p/perlunya-bk-disekolah-luar-sekolah.html> [Accessed on 20 January 2014]. (2012).

6. P. Paisley, L. Borders. School Counseling: An Evolving Specialty, Journal of Counseling and Development, 74(2) (1995) 150-153.

7. K. Cook, M. Mayorga, V. Ball. 2016. Mandala Mornings: A Creative Approach for Elementary School Counselors. Journal of School Counseling, 14(6) (2016).

8. S. Keys, F. Bemak, F, E. Lockhard. Transforming School Counseling to Serve the Mental Health Needs of At-Risk Youth, Journal of Counseling and Development, 76 (2011) 381388.

9. Mogbo, I. Obumneke-Okeke, F. Anyachebelu. Implementation of Guidance and Counseling Services in Nigerian Schools, Journal of Emerging Trends in Educational Research and Policy Studies (JETERAPS), 2(5), (2011) 361-264.

10. Betters-Bubon, P. Donohue. Professional Capacity Building For School Counselors Through School-Wide Positive Behavior Interventions And Supports Implementation. Journal of School Counseling, 14(3) (2016).

11. Epstein, F. Voorhis. School Counselors' Roles in Developing Partnerships with Families and Communities for Student Success, Professional School Counseling. (2014).1-14.

12. J. Galassi, P. Akos. Developmental Advocacy: Twenty-First Century School Counseling, Journal of Counseling and Development, 82(2) (2004) 146-157.

13. C. Dahir. Supporting a Nation of Learners: The Role of School Counseling in Educational Reform. Journal of Counseling and Development, 82 (2004) 344-353.

14. H. Rosenthal. Encyclopedia of Counseling, 3rd ed. New York: Routledge, Taylor \& Francis Group. (2008).

15. Epstein. Improving Family and Community Involvement In Secondary Schools. Education Digest, Vol. 73(6), (2008) 9-12.

16. Gatra, GATRAnews. Important, Guidance and Counseling in Inclusive Schools. [online] Available at <http://www.gatra.com/nusantara-1/nasional-1/39751-penting,-bimbingan-dan konseling-di-sekolah-inklusif.html> [Accessed on 20 December 2015]. (2013).

17. Indonesian Internet Service Provider Association (APJII). The Statistics of Indonesia Internet Users. [online] Available at $<$ http://www.apjii.or.id/v2/read/page/halaman-data/9/ statistik.html $>$ [Accessed on 20 January 2014]. (2013).

18. K. Huang. Challenges in Human-Computer Interaction Design for Mobile Devices. Proceedings of the World Congress on Engineering and Computer Science Vol. 1. (2009).

19. Indonesian Core Technologies. Application of Counseling. [online] Available at $<$ http://pusatict.com/software-aplikasi-sistem-informasi-bimbingan-konseling-bk>/, [Accessed on 20 January 2014]. (2012).

20. Masmuadi. Information System of Counseling. [online] Available at: $<$ http://infobksman3banjar.blogspot.com/2012/04/software-bk-bimbingan-konseling-hasil.html.

[Accessed on 20 January 2014]. (2012). 
21. W. Neuman. Social Research Methods: Qualitative and Quantitative Approaches, sixth edition, Pearson - Allyn and Bacon. (2006).

22. E. Turban, E. McLean, J. Wetherbe. Information Technology for Management: Transforming Business in the Digital Economy, 6th ed., Wiley, USA. (2008).

23. P. Braun. SME Networks: Clustering for Regional Innovation Purposes, In: University of Ballarat. Proceeding of 16th Annual Conference of Small Enterprise Association of Australia and New Zealand. Ballarat Victoria, Australia (2003).

24. B. Dick. Postgraduate Programs Using Action Research, The Learning Organization, 9(4), (2002) 159-170.

25. S. Limanto. Analysis of School Counseling Services Information System in Multilevel School ' $\mathrm{X}$ '. Proceeding of Applied Business and Engineering Conference (ABEC). Batam, Indonesia, (2015).

26. D. Absari, S. Setyawan. Making Design of Information Systems Counseling with a Case Study on School Multijenjang 'X'. Proceeding of Applied Business and Engineering Conference (ABEC). Batam, Indonesia, (2015). 
Figure captions

Figure 1. Student Counseling History

Figure 2. Daily Student's Case

Figure 3. Home Visit Entry

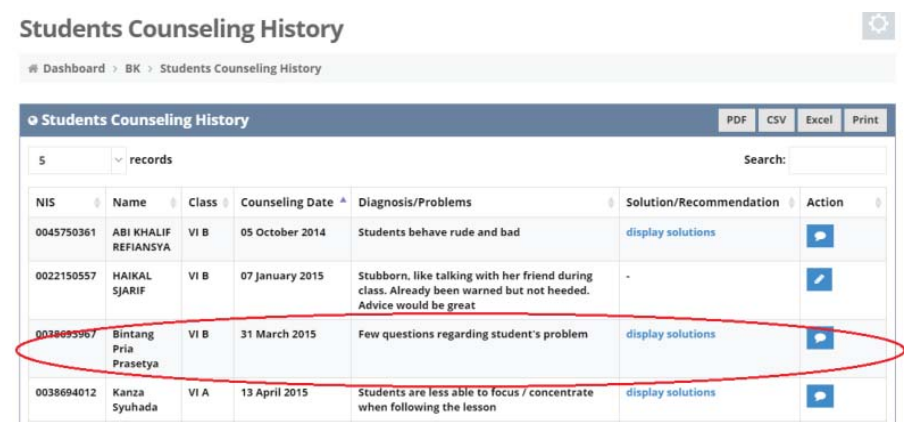

Figure 1. Susana et al

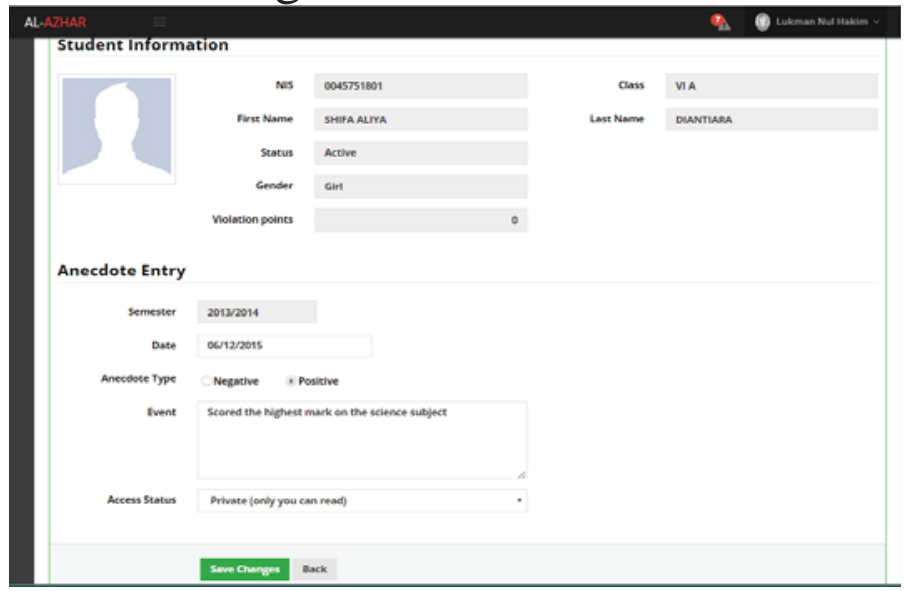

Figure 2. Susana et al

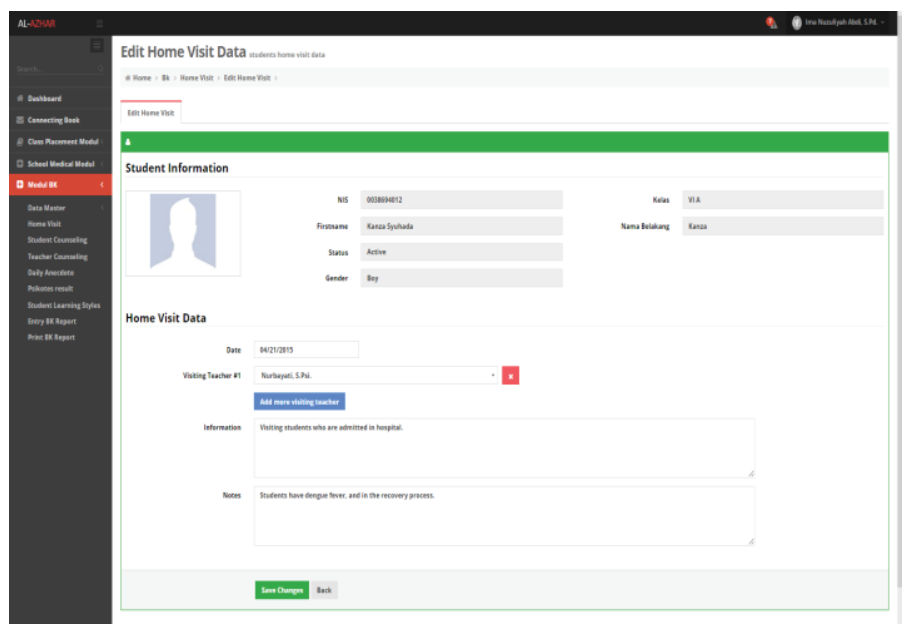

Figure 3. Susana et al 


\section{Table captions}

Table 1. Respondents' Profile

\begin{tabular}{|c|c|c|}
\hline $\begin{array}{c}\text { TYPE OF } \\
\text { RESPONDENT }\end{array}$ & $\begin{array}{c}\text { NUMBER OF } \\
\text { QUESTION- } \\
\text { NAIRE } \\
\text { DISTRIBUTED }\end{array}$ & $\begin{array}{c}\text { NUMBER OF } \\
\text { RETURNED } \\
\text { QUESTION- } \\
\text { NAIRE }\end{array}$ \\
\hline Parent & 20 & 4 \\
\hline $\begin{array}{l}\text { Classroom } \\
\text { Teacher }\end{array}$ & 10 & 8 \\
\hline $\begin{array}{l}\text { Guidance and } \\
\text { Counseling } \\
\text { Teacher }\end{array}$ & 5 & 5 \\
\hline Total & 35 & 17 \\
\hline
\end{tabular}




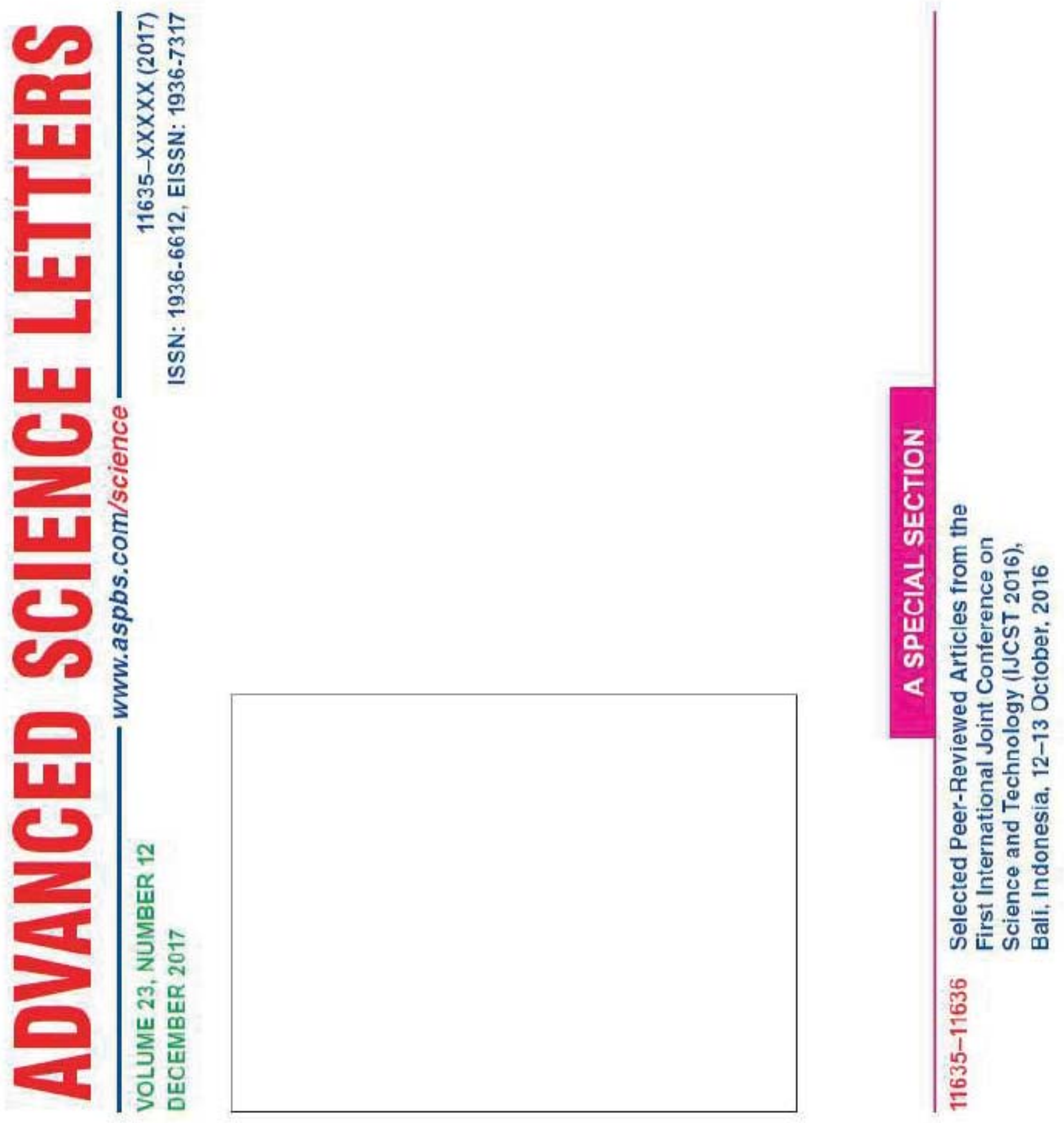




\section{Advanced}
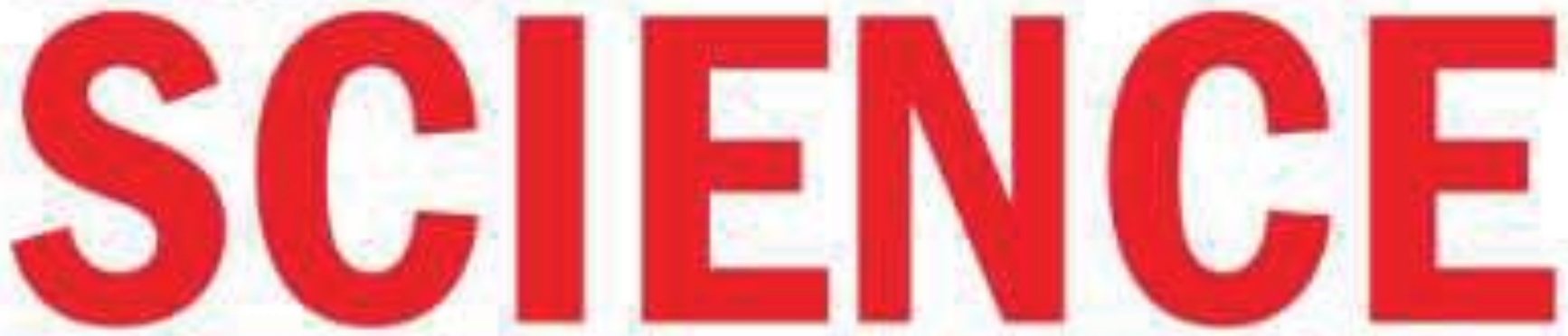

\section{A Journal Dedicated to All Aspects of Scientific Resanarch}

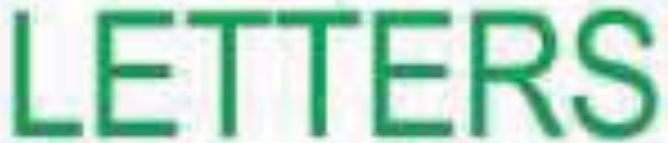

Editor-in-Chiet: Dr. Hari Singh Nalwa, USA

Special Soctions on

First inturrational Joint Genference on Science and Technology (L.JCST 2016)

Ball, indenesia, 12-13 October, 2016

QUEST EDTORS: A, P. Bwounna Eit Atwoh, Woitgang W. Sehruah, Jamani and Sheng Zhang International Conterence on Nealth, Ptarmacy and Medicine (ICHPMa017)

Jotar Batiru, Mabyaia, 26-27 Octobet, 2017

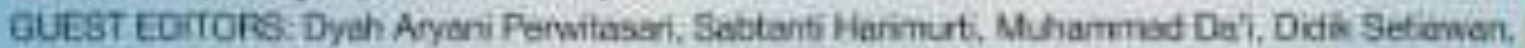
Wwik Kusumarmat, Nunik Aries Nunulita, and Abdui Aris Nimul Hidaryat

2017 International Coaference on Big Data, loT, and Cloud Competing (BIC 2017)

Jeju, Korea, 22-24 Augest, 2017

GUEST EOITORS: Gangman Yind Byoungrook Kim 


\section{Advanced Science Letters}

ISSN: 1936-6612 (Print): EISSN: 1936-7317 (Online)

Copyright ( $2000-2018$ American Scientific Publishers. All Rights Reserved.

\section{Aims and Scope}

ADVANCED SCIENCE LETTERS is a multidisciplinary peer-reviewed journal with a very wide-ranging coverage, consolidates fundamental and applied research activities by publishing proceedings from international scientific, technical and medical conferences in all areas of (1) Physical Sciences, (2) Engineering, (3) Biological Sciences/Health Sciences, (4) Medicine, (5) Computer and Information Sciences, (6) Mathematical Sciences, (7) Agriculture Science and Engineering, (8) Geosciences, and (9) Energy/Fuels/Environmental / Green Science and Engineering, and (10) Education, Social Sciences and Public Policies. This journal does not publish general research articles by individual authors.

NOTE: This journal is solely focused on special issues from conference proceedings and does not publish general research articles by individual authors.

RESEARCH TOPICS COVERED (but not limited to):

ADVANCED SCIENCE LETTERS deals with Adhesion Science and Technology, Aeronautics Engineering, Aerosol Science and Technology, Aerospace Engineering, Agriculture Engineering, Agriculture Sciences, Anthropology, Astronomical Sciences, Biochemical engineering, Biochemistry, Bioengineering, Bioinformatics, Biological Sciences, Biomedical Engineering, Biomedical Sciences, Biotechnology, Botany, Ceramic Science and Engineering, Cereal Chemistry, Chemical Biology, Chemical Engineering, Chemical Engineering, Chemistry, Civil Engineering, Clinical Sciences, Colloid Science, Communication Science, Composites Science, Computer Science, Engineering and Technology, Dairy Science, Device Engineering, Drug Discovery, Earthquake Science, Ecological Sciences, Educational Sciences, Electrical Engineering, Electronics Engineering, Energy Science and Technology, Environmental Engineering, Environmental Sciences, Enzyme Science and Engineering, Food Science, Forestry, Fuel Science, Genetics, Geosciences, Health Sciences, Hydrology, Information Technology, Interface Science, Life Sciences, Lubrication Science, Manufacturing Science, Engineering and Technology, Marine Science, Materials Science, Mathematical Sciences, Mechanical Engineering, Medicinal Chemistry, Medicinal Science, Membrane Science, Metallurgical Science and Engineering, Meteorology, Microbiology, Minerals Science, Nanoscience, Nanotechnology, Nanoengineering, Nanomedicine, Nanobiology, Neuroscience, Nutrition Science, Oceanography, Optical Engineering, Optical Sciences, Paleontology, Paper Science, Petroleum Science, Petrology, Pharmaceutical Sciences, Pharmacology, Physics, Plant Sciences, Plasma Science and Technology, Polymer Engineering, Polymer Science, Polymer Technology, Powder Technology, Seismology, Sol-Gel Science, Supramolecular Science, Surface Science, Toxicology, Vacuum Science and Technology, Virology, Waste Management, Water Science, Wood Science and Technology, Zoology, Educational Aspects in all these Research Areas, and Selected Conference Special issues on Education, Social Sciences, Public Policies at the discretion of Editor-in-Chief.

\section{READERSHIP}

The journal is intended for a very broad audience working in all fields of (1) Physical Sciences, (2) Biological Sciences, (3) Mathematical Sciences, (4) Engineering, (5) Computer and Information 
Sciences, and (6) Geosciences, etc.

\section{EDITOR-IN-CHIEF}

Dr. Hari Singh Nalwa, USA

Editorial Office:

ADVANCED SCIENCE LETTERS

American Scientific Publishers

26650 The Old Road, Suite 208

Valencia, California 91381-0751, USA

Tel. (661) 799-7200

Fax: (661) 799-7230

E-mail: science@aspbs.com

ASIAN EDITOR

Dr. Katsuhiko Ariga, PhD

Advanced Materials Laboratory

National Institute for Materials Science

1-1 Namiki, Tsukuba, Ibaraki 305-0044, JAPAN

Website: $\underline{w w w . a s p b s . c o m / s c i e n c e}$

Referee's Report

Please prepare and submit Reviewer's Report to appropriate Associate Editors accordingly.

Subscription

American Scientific Publishers

26650 The Old Road, Suite 208

Valencia, California 91381-0751, USA

Tel. (661) 799-7200

Fax: (661) 799-7230

Email: order@aspbs.com

Annual Subscription Rates (Print Edition) for 2008

Personal: US\$ 200 (Domestic) / US\$250 (Foreign Countries)

Institutional: US\$ 500 (Domestic) / US\$ 600 (Foreign Countries)

Postage and handling: add \$30 for USA and \$50 for foreign countries

Web Edition

ADVANCED SCIENCE LETTERS will be available via internet. For subscription rates to Web Edition, please contact publisher.

Book for Review

Publications should be sent the Editorial Office. 
Advertising

American Scientific Publishers

26650 The Old Road, Suite 208

Valencia, California 91381-0751, USA

Tel. (661) 799-7200

Fax: (661) 799-7230

Email: order@aspbs.com 


\title{
Advanced Science Letters
}

ISSN: 1936-6612 (Print): EISSN: 1936-7317 (Online)

Copyright (C 2000-2018 American Scientific Publishers. All Rights Reserved.

\section{EDITORIAL BOARD}

\author{
EDITOR-IN-CHIEF \\ Dr. Hari Singh Nalwa, USA
}

\section{Editorial Office:}

ADVANCED SCIENCE LETTERS

American Scientific Publishers

26650 The Old Road, Suite 208

Valencia, California 91381-0751, USA

Tel. (661) 799-7200

Fax: (661) 799-7230

E-mail: science@aspbs.com

\section{ASIAN EDITOR}

Dr. Katsuhiko Ariga, PhD

Advanced Materials Laboratory

National Institute for Materials Science

1-1 Namiki, Tsukuba, Ibaraki 305-0044, JAPAN

\section{ASSOCIATE EDITORS}

Diederik Aerts (Quantum theory, Cognition, Evolution theory)

Brussels Free University, Belgium.

Yakir Aharonov (Physics, Quantum Physics)

School of Physics and Astronomy, Israel.

Peter C. Aichelburg (Gravitation)

University of Vienna, Austria.

Jim Al-Khalili (Foundations of Physics, Nuclear Reaction Theory)

University of Surrey, UK.

Jake Blanchard (Engineering Physics, Nuclear Engineering)

University of Wisconsin-Madison, USA. 
Simon Baron-Cohen (Cognitive Neuroscience)

University of Cambridge, UK.

Franz X. Bogner (Cognitive Achievement)

University of Bayreuth, Germany.

John Borneman (Anthropology)

Princeton University, USA.

John Casti (Complexity Science)

Internationales Institut für Angewandte Systemanalyse, Austria.

Masud Chaichian (High Energy Physics, String Theory)

University of Helsink, Finland.

Sergey V. Chervon(Gravitation, Cosmology, Astrophysics)

Ulyanovsk State Pedagogical University, Russia

Kevin Davey (Philosophy of Science)

University of Chicago, Chicago, USA.

Tania Dey (Colloids/Polymers/Nanohybrids)

Canada.

Roland Eils (Bioinformatics)

Deutsches Krebsforschungszentrum Heidelberg, Germany.

Thomas Görnitz (Quantum theory, Cosmology)

University of Frankfurt, Germany.

Bert Gordijn (Nanoethics, Neuroethics, Bioethics)

Radboud University Nijmegen, The Netherlands.

Ji-Huan He (Textile Engineering, Functional Materials)

Soochow University, Suzhou, China.

Nongyue He (Biosensors/Biomaterials)

China.

Irving P. Herman (Materials and Solid State Physics)

Columbia University, USA. 
Dipankar Home (Foundations of Quantum Mechanics)

Bose Institute, Kolkata, India.

Jucundus Jacobeit (Climate, Global Change Ecology)

University of Augsburg, Germany.

Yuriy A. Knirel (Bioorganic Chemistry)

N. D. Zelinsky Institute of Organic Chemistry, Russia.

Arthur Konnerth (Neurophysiology, Molecular Mechanisms)

University of Munich, Germany.

G. A. Kourouklis (Physics Solid State Physics)

Aristotle University Thessaloniki, Greece.

Peter Krammer (Genetics)

Deutsches Krebsforschungszentrum Heidelberg, Germany.

Andrew F. Laine (Biomedical Engineering)

Columbia University, USA.

Minbo Lan (Organic Functional Materials)

China.

Martha Lux-Steiner (Physics, Materials Science)

Hahn-Meitner-Institut Berlin, Germany.

Klaus Mainzer (Complex Systems, Computational Mind, Philosophy of Science)

University of Augsburg, Germany.

JoAnn E. Manson (Medicine, Cardiovascular Disease)

Harvard University, USA.

Mark P. Mattson (Neuroscience)

National Institute on Aging, Baltimore, USA.

Lucio Mayer (Astrophysics, Cosmology)

ETH Zürich, Switzerland.

Karl Menten (Radioastromy)

Max-Planck-Institut für Radioastromie, Germany. 
Yoshiko Miura (Biomaterials/Biosensors)

Japan.

Fred M. Mueller (Solid State Physics)

Los Alamos National Laboratory, USA.

Garth Nicolson (IIlness Research, Cancer Cell Biology)

The Institute for Molecular Medicine, Huntington Beach, USA.

Nina Papavasiliou (DNA Mutators, Microbial Virulence, Antiviral Defence, Adaptive Immunity, Surface Receptor Variation)

The Rockefeller University, New York, USA.

Panos Photinos (Physics)

Southern Oregon University, USA.

Zhiyong Qian (Biomedical Engineering, Biomaterials, Drug Delivery)

Sichuan University, CHINA.

Reinhard Schlickeiser (Astrophysics, Plasma Theory and Space Science)

Ruhr-Universität Bochum, Germany.

Surinder Singh (Sensors/Nanotechnology)

USA.

Suprakas Sinha Ray (Composites/Polymer Science)

South Africa.

Koen Steemers (Architechture, Environmental Building Performance)

University of Cambridge, UK.

Shinsuke Tanabe (Environmental Chemistry and Ecotoxicology)

Ehime University, Japan.

James R. Thompson (Solid State Physics)

The University of Tennessee, USA.

Uwe Ulbrich (Climat, Meteorology)

Freie Universität Berlin, Germany.

Ahmad Umar (Advanced Materials)

Najran University, Saudi Arabia. 
Frans de Waal (Animal Behavior and Cognition)

Emory University, USA.

\section{EDITORIAL BOARD}

Filippo Aureli, Liverpool John Moores University, UK

Marcel Ausloos, Université de Liège, Belgium

Martin Bojowald, Pennsylvania State University, USA

Sougato Bose, University College, London, UK

Jacopo Buongiorno, MIT, USA

Paul Cordopatis, University of Patras, Greece

Maria Luisa Dalla Chiara, University of Firenze, Italy

Dionysios Demetriou Dionysiou, University of Cincinnati, USA

Simon Eidelman, Budker Institute of Nuclear Physics, Russia

Norbert Frischauf, QASAR Technologies, Vienna, Austria

Toshi Futamase, Tohoku University, Japan

Leonid Gavrilov, University of Chicago, USA

Vincent G. Harris, Northeastern University, USA

Mae-Wan Ho, Open University, UK

Keith Hutchison, University of Melbourne, Australia

David Jishiashvili, Georgian Technical University, Georgia

George Khushf, University of South Carolina, USA

Sergei Kulik, M.V.Lomonosov Moscow State University, Russia

Harald Kunstmann, Institute for Meteorology and Climate Research, Forschungszentrum Karlsruhe, Germany

Alexander Lebedev, Laboratory of Semiconductor Devices Physics, Russia

James Lindesay, Howard University, USA

Michael Lipkind, Kimron Veterinary Institute, Israel

Nigel Mason, Open University, UK

Johnjoe McFadden, University of Surrey, UK

B. S. Murty, Indian Institute of Technology Madras, Chennai, India

Heiko Paeth, Geographisches Institut der Universität Würzburg, Germany

Matteo Paris, Universita' di Milano, Italia

David Posoda, University of Vigo, Spain

Paddy H. Regan, University of Surrey, UK

Leonidas Resvanis, University of Athens, Greece

Wolfgang Rhode, University of Dortmund, Germany

Derek C. Richardson, University of Maryland, USA

Carlos Romero, Universidade Federal da Paraiba, Brazil

Andrea Sella, University College London, London, UK

P. Shankar, Indira Gandhi Centre for Atomic Research, Kalpakkam, India

Surya Singh, Imperial College London, UK 
Leonidas Sotiropoulos, University of Patras, Greece

Roger Strand, University of Bergen, Norway

Karl Svozil, Technische Universität Wien, Auastria

Kit Tan, University of Copenhagen, Denmark

Roland Triay, Centre de Physique Theorique, CNRS, Marseille, France

Rami Vainio, University of Helsinki, Finland

Victor Voronov, Bogoliubov Laboratory of Theoretical Physics, Dubna, Russia

Andrew Whitaker, Queen's University Belfast, Northern Ireland

Lijian Xu, Hunan University of Technology, China

Alexander Yefremov, Peoples Friendship University of Russia, Russia

Avraam Zelilidis, University of Patras, Greece

Alexander V. Zolotaryuk, Ukrainian Academy of Sciences, Ukraine 


\section{Advanced Science Letters}

ISSN: 1936-6612 (Print): EISSN: 1936-7317 (Online)

Copyright (C) 2000-2018 American Scientific Publishers. All Rights Reserved.

EDITOR-IN-CHIEF

Dr. Hari Singh Nalwa, USA

Editorial Office:

ADVANCED SCIENCE LETTERS

American Scientific Publishers

26650 The Old Road, Suite 208

Valencia, California 91381-0751, USA

Tel. (661) 799-7200

Fax: (661) 799-7230

E-mail: science@aspbs.com

ASIAN EDITOR

Dr. Katsuhiko Ariga, PhD

Advanced Materials Laboratory

National Institute for Materials Science

1-1 Namiki, Tsukuba, Ibaraki 305-0044, JAPAN

Subscription

American Scientific Publishers

26650 The Old Road, Suite 208

Valencia, California 91381-0751, USA

Tel. (661) 799-7200

Fax: (661) 799-7230

Email: order@aspbs.com 


\title{
Advanced Science Letters
}

ISSN: 1936-6612 (Print): EISSN: 1936-7317 (Online)

Copyright (C) 2000-2018 American Scientific Publishers. All Rights Reserved.

\author{
Abstracting and Indexing \\ - Conference Proceedings Citation Index-Science (CPCI-S) \\ - Chemical Abstracts \\ - Biological Sciences Abstracts \\ - Biotechnology and BioEngineering Abstracts \\ - Biotechnology Research Abstracts \\ - Bacteriology Abstracts (Microbiology B) \\ - Neurosciences Abstracts \\ - Engineering Research Database \\ - Technology Research Database \\ - Environmental Science and Pollution Management
}


Volume 23, Number 12 (December 2017) pp.11635-12838

A SPECIAL SECTION

Selected Peer-Reviewed Articles from the First International Joint Conference on Science and Technology

(IJCST 2016), Bali, Indonesia, 12-13 October, 2016

Guest Editors: A. P. Bayuseno, Bill Atweh, Wolfgang W. Schmahl, Jamari, and Sheng Zhang

Adv. Sci. Lett. 23, 11635-11636 (2017)

[Abstract] [Full Text - PDF] [Purchase Article]

\section{RESEARCH ARTICLES}

Land Requirement for Food in Ngawi Regency

Agus Sutedjo

Adv. Sci. Lett. 23, 11637-11640 (2017)

[Abstract] [Full Text - PDF] [Purchase Article]

Spasio-Temporal Variability of the Vegetation Cover Density in the Gunungsewu Karst Landscape Based on

Landsat 8 OLI Data

Eko Budiyanto

Adv. Sci. Lett. 23, 11641-11644 (2017)

[Abstract] [Full Text - PDF] [Purchase Article]

Juridical Issues of Foreign Labor in Asean Economic Community Era

Arinto Nugroho

Adv. Sci. Lett. 23, 11645-11648 (2017)

[Abstract] [Full Text - PDF] [Purchase Article]

Media to Counter Radicalization: A Case Study at Islamic (Boarding) Schools

Tsuroyya

Adv. Sci. Lett. 23, 11649-11653 (2017)

[Abstract] [Full Text - PDF] [Purchase Article]

Social and Personal Factors to Become Elementary Teacher

Danang Tandyonomanu, Tsuroyya, and Awang Dharmawan

Adv. Sci. Lett. 23, 11654-11657 (2017)

[Abstract] [Full Text - PDF] [Purchase Article]

The Study of the Factors That Influence the Community to Survive Living in the Disaster Area

Ita Mardiani Zain, Sulistinah, and Drianda Immanuel Prasetya

Adv. Sci. Lett. 23, 11658-11661 (2017)

[Abstract] [Full Text - PDF] [Purchase Article] 
Development of Tourism in Kediri Regency Destination as the Local and National Sri Murtini and L. Sudaryono

Adv. Sci. Lett. 23, 11662-11665 (2017)

[Abstract] [Full Text - PDF] [Purchase Article]

Democratic Society in the Local Wisdom: Citizen Participatory Activity in the Environmental Movement

Maya Mustika Kartika Sari

Adv. Sci. Lett. 23, 11666-11669 (2017)

[Abstract] [Full Text - PDF] [Purchase Article]

Increasing the Productivity of Chips Manufacturers Through Utilization of Chip Raw

Materials Chopper

and Oil Drying Machine

Sukma Perdana Prasetya

Adv. Sci. Lett. 23, 11670-11673 (2017)

[Abstract] [Full Text - PDF] [Purchase Article]

Jokowi's Political Branding for the Victory of the President

Agus Machfud Fauzi

Adv. Sci. Lett. 23, 11674-11677 (2017)

[Abstract] [Full Text - PDF] [Purchase Article]

The Carrying Capacity Ratio (CCR) Analysis of Meteoric Water Resources at the Middle East Java Region

Bambang Hariyanto

Adv. Sci. Lett. 23, 11678-11682 (2017)

[Abstract] [Full Text - PDF] [Purchase Article]

Social Media and Spiritual Content: A Descriptive Analysis of Facebook and SalingSapa.com Vinda Maya Setianingrum

Adv. Sci. Lett. 23, 11683-11686 (2017)

[Abstract] [Full Text - PDF] [Purchase Article]

Behavior of Bonek Supporters in the Perspective Subculture of Violence Rr. Nanik Setyowati

Adv. Sci. Lett. 23, 11687-11691 (2017)

[Abstract] [Full Text - PDF] [Purchase Article]

Strengthening Educational Function of Family Welfare Empowerment Movement:

Educational Aids on

Gender for Democracy

Oksiana Jatiningsih

Adv. Sci. Lett. 23, 11692-11696 (2017)

[Abstract] [Full Text - PDF] [Purchase Article] 
Revitalization of Traditional Market Based on Deliberative Democracy Concept Agus Prastyawan

Adv. Sci. Lett. 23, 11697-11701 (2017)

[Abstract] [Full Text - PDF] [Purchase Article]

Building Students' Multicultural Values Through Citizenship Education to Create a Democratic Society

Totok Suyanto, Rr. Nanik Setyowati, and Made Pramono

Adv. Sci. Lett. 23, 11702-11705 (2017)

[Abstract] [Full Text - PDF] [Purchase Article]

Role of Organization Culture Performance for Primary School Teachers

Suharningsih

Adv. Sci. Lett. 23, 11706-11709 (2017)

[Abstract] [Full Text - PDF] [Purchase Article]

Effective Self-Management Affect the Performance of Teacher Primary School

Murtedjo

Adv. Sci. Lett. 23, 11710-11714 (2017)

[Abstract] [Full Text - PDF] [Purchase Article]

Religion Spirit to the Development of Modern Science; Synergies Between Reason and Revelation

M. Turhan Yani

Adv. Sci. Lett. 23, 11715-11718 (2017)

[Abstract] [Full Text - PDF] [Purchase Article]

Mediation Over Disputes Between Indigenous People and Industrial Plantation Forest Businessmen in Indonesia

Tamsil and Mahendra Wardhana

Adv. Sci. Lett. 23, 11719-11722 (2017)

[Abstract] [Full Text - PDF] [Purchase Article]

Legal Protection of Traditional Knowledge, Recognition and Certainty of Property Protection of Traditional

Knowledge of Indigenous Peoples

Indri Fogar Susilowati and Budi Hermono

Adv. Sci. Lett. 23, 11723-11726 (2017)

[Abstract] [Full Text - PDF] [Purchase Article]

Legal Protection for Victims of Bullying in the Learning Process in Terms of Epistemology

Nurul Hikmah and Pudji Astuti

Adv. Sci. Lett. 23, 11727-11730 (2017)

[Abstract] [Full Text - PDF] [Purchase Article]

Rethinking on Criminalizing of Defamation (Evaluation of Criminal Policy) 
Emmilia Rusdiana and Pudji Astuti

Adv. Sci. Lett. 23, 11731-11734 (2017)

[Abstract] [Full Text - PDF] [Purchase Article]

Manuscript Controversy Issue Boekhandel Tan Khoen Swie Kediri (Historical Studies)

Wisnu, SeptinaAlrianingrum, and Artono

Adv. Sci. Lett. 23, 11735-11738 (2017)

[Abstract] [Full Text - PDF] [Purchase Article]

Messianic Figures in the Late Period of Majapahit: An Anthropological Approach in Historical Archaeology Issues

Y. Hanan Pamungkas, Agus Trilaksana, and Sumarno

Adv. Sci. Lett. 23, 11739-11743 (2017)

[Abstract] [Full Text - PDF] [Purchase Article]

Existence of Nation: Indonesian Football in Melbourne Olympics 1956

Rojil Nugroho Bayu Aji, Eko Satriya Hermawan, and Riyadi

Adv. Sci. Lett. 23, 11744-11747 (2017)

[Abstract] [Full Text - PDF] [Purchase Article]

Needs-Based Poverty Reduction in Rural Areas

Sugeng Harianto

Adv. Sci. Lett. 23, 11748-11752 (2017)

[Abstract] [Full Text - PDF] [Purchase Article]

An Intercultural Communication Dereliction and Prejudice: A Case Study in Sampang District, Madura, Indonesia

Awang Dharmawan

Adv. Sci. Lett. 23, 11753-11757 (2017)

[Abstract] [Full Text - PDF] [Purchase Article]

Developing Learning History as Emancipatory Education

Agus Suprijono

Adv. Sci. Lett. 23, 11758-11761 (2017)

[Abstract] [Full Text - PDF] [Purchase Article]

Construction and Strategies for Strengthening the Value of Integrity for Students to Build a

Culture Dignity

and Competitively in Universitas Negeri Surabaya

Sarmini and Ketut Prasetyo

Adv. Sci. Lett. 23, 11762-11765 (2017)

[Abstract] [Full Text - PDF] [Purchase Article]

The Role of Family in Gender Equality Building

Listyaningsih

Adv. Sci. Lett. 23, 11766-11769 (2017) 


\section{[Abstract] [Full Text - PDF] [Purchase Article]}

The Meaning of Coffee Shop for the Young People in Aceh

Sarmini, Ridwan, Ani Wakidah Basriani, and Ulin Nadiroh

Adv. Sci. Lett. 23, 11770-11775 (2017)

[Abstract] [Full Text - PDF] [Purchase Article]

Nationalism Construction in the Young People in Surabaya East Java

Sarmini and Warsono

Adv. Sci. Lett. 23, 11776-11780 (2017)

[Abstract] [Full Text - PDF] [Purchase Article]

The Roles of Parents in Building Family Harmony in Early Marriage Couple in Madura Sarmini, Abdul Majid, Syarifah Hasanah, Ulin Nadiroh, and Hestin Sri Widiawati

Adv. Sci. Lett. 23, 11781-11786 (2017)

[Abstract] [Full Text - PDF] [Purchase Article]

Developing Strategy for Rice Milling Unit Selection Process Using Analytical Hierarchy Process (AHP) Method:

A Case of Agroindustry in Indonesia

I. B. Suryaningrat and Angela Fianeka

Adv. Sci. Lett. 23, 11787-11792 (2017)

[Abstract] [․ㅏll Text - PDF] [Purchase Article]

Quality Characteristics of Natural Edamame Jam Without Preservative Ingredient as

Supplementary of

Emergency Food

Nurhayati Nurhayati and Ahmad Rizky Alfian

Adv. Sci. Lett. 23, 11793-11796 (2017)

[Abstract] [Full Text - PDF] [Purchase Article]

Savory Salt Production by Enzymatic Hydrolysis from Low Economic Value of Freshwater Fishes and

Saltwater Fishes

Yuli Witono, Iwan Taruna, Wiwik Siti Windrati, Lailatul Azkiyah, Tomoyuki Yoshino, and Ria Dewi Nurani

Adv. Sci. Lett. 23, 11797-11799 (2017)

[Abstract] [Full Text - PDF] [Purchase Article]

Superiority of Two Stage Anaerobic Fixed Bed Reactors in Handling Organic Shock Loads Herawati Budiastuti, Dewi Widyabudiningsih, Dianty Rosirda Dewi Kurnia, and Endang Sri

Rahayu

Adv. Sci. Lett. 23, 11800-11803 (2017)

[Abstract] [Full Text - PDF] [Purchase Article]

Heat Integration Between HVU and FCCU to Improve Energy Saving 
Sintha Soraya Santi, Renanto, and Ali Altway

Adv. Sci. Lett. 23, 11804-11809 (2017)

[Abstract] [Full Text - PDF] [Purchase Article]

Characterization of IR Spectra and Molecular Weight of the Products on Modified Ring Opening Polymerization

of Poly Lactid Acid

Yenny Meliana, Gatot Ibnusantosa, and Agus Haryono

Adv. Sci. Lett. 23, 11810-11814 (2017)

[Abstract] [Full Text - PDF] [Purchase Article]

Characterization of Emulsion System on Mimba Oil as Organic Insecticide Using Surfactants Based on Vegetable Oil

Savitri and Yenny Meliana

Adv. Sci. Lett. 23, 11815-11818 (2017)

[Abstract] [Full Text - PDF] [Purchase Article]

Synthesis and Characterization of Palm Oil and Polyethylene Glycol Based Polymeric Surfactants

Yan Irawan, Ika Juliana, and Indri Badria Adilina

Adv. Sci. Lett. 23, 11819-11823 (2017)

[Abstract] [Full Text - PDF] [Purchase Article]

Economic Analysis and Development Strategies for Leading Products in Sampang District Akhmad Fauzi, Kustini, Bowo Santoso, and Edy Mulyadi

Adv. Sci. Lett. 23, 11824-11827 (2017)

[Abstract] [Full Text - PDF] [Purchase Article]

Effect of Pressure on the Supercritical $\mathrm{CO}_{2}$ Extraction of Asiaticoside from Centella asiatica Dewi Sondari, Tun Tedja Irawadi, Dwi Setyaningsih, and Silvester Tursiloadi

Adv. Sci. Lett. 23, 11828-11833 (2017)

[Abstract] [Full Text - PDF] [Purchase Article]

Alkoxy Groups of Sulfonated Natural Oil-Based Surfactant to Reduce Oil-Water Interfacial Tension for

Chemical Flooding

Yani F. Alli, Usman, and Letty Brioletty

Adv. Sci. Lett. 23, 11834-11837 (2017)

[Abstract] [Full Text - PDF] [Purchase Article]

Risk Allocation for Low-Cost Apartment Program Implementation in the Surabaya Metropolitan Area

M. Muntoha, Ria A. A. Soemitro, and Farida Rachmawati

Adv. Sci. Lett. 23, 11838-11842 (2017)

[Abstract] [Full Text - PDF] [Purchase Article] 
The Effect of Detention Time and Plant Density to the Effectivity of Constructed Wetland as Wastewater

Treatment Innovation in Small Industry of Cassava Chips

Erina Rahmadyanti, Andre Dwijanto Witjaksono, and Ulil Hartono

Adv. Sci. Lett. 23, 11843-11847 (2017)

[Abstract] [Full Text - PDF] [Purchase Article]

The Influence of Organizational Culture and Job Satisfaction on Organizational Citizenship Behavior (OCB)

with Organizational Commitment as Intervening Variable at PT. Cartenz Indonesia in Solo City-Indonesia

Wiji Utami, Lilik Farida, Nadia Azalia, and Muhammad Lutfi

Adv. Sci. Lett. 23, 11848-11852 (2017)

[Abstract] [Full Text - PDF] [Purchase Article]

Developing a Harmony Ethnic Plurality in Pohuwato Society in Public Administration Perspective

Wantu Sastro and Tamu Yoan

Adv. Sci. Lett. 23, 11853-11856 (2017)

[Abstract] [Full Text - PDF] [Purchase Article]

Optimizing Product Mix Using Linear Programming: A Case Study of 'Kopi Sembilan' Andre Dwijanto Witjaksono, Erina Rahmadyanti, and Dwiarko Nugrohoseno

Adv. Sci. Lett. 23, 11857-11862 (2017)

[Abstract] [Full Text - PDF] [Purchase Article]

Land Use Prospects and Challenges on Intermodal Terminal, Juanda International Airport Amanda Ristriana Pattisinai, Anita Susanti, and Ari Widayanti

Adv. Sci. Lett. 23, 11863-11866 (2017)

[Abstract] [Full Text - PDF] [Purchase Article]

The Use of Fuzzy Logic in Developing Competitiveness Strategy Toward Small and Medium Enterprises (Grocery)

Arasy Alimudin, Soebandi, Achmad Zakki Falani, Eman Setiawan, and Bustomi Arifin

Adv. Sci. Lett. 23, 11867-11873 (2017)

[Abstract] [Full Text - PDF] [Purchase Article]

School Counseling Services Information System Optimization in Multi-Level School at Surabaya

Susana Limanto, Andre, Dhiani Tresna Absari, and Sholeh Hadi Setyawan

Adv. Sci. Lett. 23, 11874-11878 (2017)

[Abstract] [Full Text - PDF] [Purchase Article]

Classification of Lung Disease Syndromes in Traditional Chinese Medicine Based on Learning Vector Quantization

I. G. P. Asto Buditjahjanto, Naim Rochmawati, and R. Hapsari Peni 
Adv. Sci. Lett. 23, 11879-11883 (2017)

[Abstract] [Full Text - PDF] [Purchase Article]

The Ammoniation-A Way for Evolving the Rural Areas, Madura Island, Indonesia Soedarto Teguh, Soemartono, Syaifuddin Zuhri, and Ertien Rining

Adv. Sci. Lett. 23, 11884-11888 (2017)

[Abstract] [Full Text - PDF] [Purchase Article]

Computer Utilization as a Balanced Opponent in Dam-Dam-An

Setiawan Wibowo Purnomo, Susana Limanto, and Monica Widiasri

Adv. Sci. Lett. 23, 11889-11891 (2017)

[Abstract] [Full Text - PDF] [Purchase Article]

Beef Weight Prediction System Based on Image Processing in Order to Increase Livestock Productivity

Lilik Anifah, Nurhayati, Haryanto, Rina Harimurti, Anita Qoiriah, and Ekohariadi

Adv. Sci. Lett. 23, 11892-11896 (2017)

[Abstract] [Full Text - PDF] [Purchase Article]

Effect of PWM Signal on Hydrogen Production Using Hoffman Voltameter Methods

Wahyuni Martiningsih, Rocky Alfanz, M. A. Akbar, Joddy Arya Laksmono, and Yenny Meliana

Adv. Sci. Lett. 23, 11897-11901 (2017)

[Abstract] [Full Text - PDF] [Purchase Article]

Determining Optimal Toolpath Strategy in the Manufacture of Insole Shoe Orthotic Made from Eva Foam

Rubber for Diabetes Patients

B. Bawono, P. W. Anggoro, A. A. Anthony, J. Jamari, and A. P. Bayuseno

Adv. Sci. Lett. 23, 11902-11909 (2017)

[Abstract] [Full Text - PDF] [Purchase Article]

Optimization of Manufacturing Process Parameters for the Product of ISO-Diabetes Patients with High Risk Classes

P. W. Anggoro, B. Bawono, J. Wibowo, J. Jamari, and A. P. Bayuseno

Adv. Sci. Lett. 23, 11910-11917 (2017)

[Abstract] [Full Text - PDF] [Purchase Article]

Comparison of the Effect of Texturing Modes and Boundary Slip on Tribological Performance of Journal Bearing

Mohammad Tauviqirrahman, Bayu Kurniawan, Rifky Ismail, Susilowati, and Jamari

Adv. Sci. Lett. 23, 11918-11921 (2017)

[Abstract] [Full Text - PDF] [Purchase Article]

Design of Shadow Trainer Equipment to Measure the Agility of Badminton Player Agung Prijo Budijono and Pudjijuniarto

Adv. Sci. Lett. 23, 11922-11927 (2017) 


\section{[Abstract] [Full Text - PDF] [Purchase Article]}

Syariah-Based Contract Farming as a Socio-Business Model: Experience of Local Phenomena Hamidah Hendrarini and Sumartono

Adv. Sci. Lett. 23, 11928-11932 (2017)

[Abstract] [Full Text - PDF] [Purchase Article]

The Model "Orientasi IPA" to Improve the Critical Thinking Skills of Senior High School Students

Budi Jatmiko, Zainul Arifin Imam Supardi, and Rosyid

Adv. Sci. Lett. 23, 11933-11937 (2017)

[Abstract] [Full Text - PDF] [Purchase Article]

The Effectiveness of Different Diluent Media as the Storage Medium for Human Sperm: To Maintain Its Quality

Isnawati, Tjandrakirana, and Nur Ducha

Adv. Sci. Lett. 23, 11938-11942 (2017)

[Abstract] [Full Text - PDF] [Purchase Article]

Implementation of Science Character Values with Green Chemistry Insight Integrated on Basic Chemistry

Course by Using Project Based Learning

Mitarlis, Bertha Yonata, and Rusly Hidayah

Adv. Sci. Lett. 23, 11943-11947 (2017)

[Abstract] [Full Text - PDF] [Purchase Article]

Qualitative Study of Antibacterial Activity of Chitosan- $\mathrm{ZnO} / \mathrm{Al}_{2} \mathrm{O}_{3}$ Nanocomposites

Dina Kartika Maharani, Rusly Hidayah, and Lailatul Khasanah

Adv. Sci. Lett. 23, 11948-11951 (2017)

[Abstract] [Full Text - PDF] [Purchase Article]

Product and Process Performance Improvement of Candidate Physics Teachers by Implementation of an

Integrated Learning Strategy

Dwikoranto, Madlazim, Eko Hariyono, and Dyah Permata Sari

Adv. Sci. Lett. 23, 11952-11955 (2017)

[Abstract] [Full Text - PDF] [Purchase Article]

The Effect of Combine Between Dietary Protein Level Variation and Laserpuncture Induction on Catfish

(Clarias sp) Oocyte Development

Dyah Hariani, Erlix R. Purnama, and Pungky Slamet Wisnu Kusuma

Adv. Sci. Lett. 23, 11956-11961 (2017)

[Abstract] [Full Text - PDF] [Purchase Article]

The Formulation of Biopesticide Combination (SpltMNPV Virus, Beauveria bassiana and 
Neem Seed

(Azadirachta indica A. Juss.) as Biocontrol Agents Against Soybean Pest

Evie Ratnasari, Mahanani Tri Asri, and Winarsih

Adv. Sci. Lett. 23, 11962-11966 (2017)

[Abstract] [Full Text - PDF] [Purchase Article]

Learning Model of the Basic Physics to Improve Concept Understanding and Critical Thinking Skills

Hainur Rasid Achmadi, Budi Jatmiko, and Wasis

Adv. Sci. Lett. 23, 11967-11971 (2017)

[Abstract] [Full Text - PDF] [Purchase Article]

Effectiveness of Ruminant Feed Formula from the Fermented Water Hyacinth (Eichhornia crassipes) to

Produce the High Level Protein of Goat Meat

Herlina Fitrihidajati and Isnawati Evie Ratnasari

Adv. Sci. Lett. 23, 11972-11975 (2017)

[Abstract] [Full Text - PDF] [Purchase Article]

Building the Design of Blended Learning in Web Lite-Based and Industrial Visits Inorganic Chemical Course

Kusumawati Dwiningsih, Sukarmin, and Muchlis

Adv. Sci. Lett. 23, 11976-11981 (2017)

[Abstract] [Full Text - PDF] [Purchase Article]

The Role of Yacon Fructooligosaccharides on the Bile Acids Binding and Bile Salt Hydrolase Activities

Leny Yuanita, Prima Retno Wikandari, and Wahyu Budi Sabtiawan

Adv. Sci. Lett. 23, 11982-11985 (2017)

[Abstract] [Full Text - PDF] [Purchase Article]

Earthquake Broadband-Noises Experiments: Spectrogram and Spectral Analysis for Hydrocarbon

Reservoir Detection

Madlazim and Tjipto Prastowo

Adv. Sci. Lett. 23, 11986-11990 (2017)

[Abstract] [Full Text - PDF] [Purchase Article]

Some Convergence Theorems on $\mathbf{\delta}$-Denjoy Integral

Manuharawati

Adv. Sci. Lett. 23, 11991-11994 (2017)

[Abstract] [Full Text - PDF] [Purchase Article]

Developing Teacher's Guidebook for Implementing Authentic Assessment in Learning Mathematics Using

Scientific Approach 
Masriyah

Adv. Sci. Lett. 23, 11995-12001 (2017)

[Abstract] [Full Text - PDF] [Purchase Article]

Synthesis of Nano $\mathrm{SiO}_{2}$ Powders from Lusi with Continuous Method

Munasir, A. J. Hairin Pribadi, Z. A. Imam Supardi, Moch. Zainuri, Triwikantoro, and Darminto

Adv. Sci. Lett. 23, 12002-12006 (2017)

[Abstract] [Full Text - PDF] [Purchase Article]

Effect Egg Yolk in CEP Extender for Sperm Capacitation of Bull During Storage at Temperature 4-5 ?C

Nur Ducha, Trinil Susilawati, Aulanni'am, and Sri Wahyuningsih

Adv. Sci. Lett. 23, 12007-12011 (2017)

[Abstract] [Full Text - PDF] [Purchase Article]

A Comparative Study of PCA, FFT and Wavelet as Feature Extraction for Gamelan Tones Recognition

Atik Wintarti, Elly Matul Imah, and Joko Winarko

Adv. Sci. Lett. 23, 12012-12015 (2017)

[Abstract] [Full Text - PDF] [Purchase Article]

Analysis of Cypermethrin Using an Electrode Solid Copper Amalgams Developed as a Working Electrode

in Differential Pulse Voltammetry Compared with Gas Chromatography Methods

Pirim Setiarso and I. Gusti Made Sanjaya

Adv. Sci. Lett. 23, 12016-12019 (2017)

[Abstract] [Full Text - PDF] [Purchase Article]

Yeast Hydrolysate Enzymatic (YHE) as Degradation Result Using Pineapple's Bromelain as Preparation

Material of Microbiology Culture Media

Rudiana Agustini and Mirwa Adiprahara

Adv. Sci. Lett. 23, 12020-12024 (2017)

[Abstract] [Full Text - PDF] [Purchase Article]

Characterization of Mesoporous NaZSM-5 and $\mathrm{K}_{3} \mathrm{PO}_{4} / \mathrm{NaZSM}-5$ from Adsorption and Desorption Isotherms

Samik, Ratna Ediati, and Didik Prasetyoko

Adv. Sci. Lett. 23, 12025-12028 (2017)

[Abstract] [Full Text - PDF] [Purchase Article]

Promoting Pre-Service Chemistry Teachers' Environmental Value Orientation and Creative Thinking Skill

Through the Implementation of Green Chemistry Laboratory Learning

Sri Poedjiastoeti, Suyono, Bertha Yonata, and Arini Siti Wahyuningsih

Adv. Sci. Lett. 23, 12029-12032 (2017) 


\section{[Abstract] [Full Text - PDF] [Purchase Article]}

Nest Development of Two Type Edible Nest in Gresik. East Java

Sunu Kuntjoro and Ayu Vitasari

Adv. Sci. Lett. 23, 12033-12036 (2017)

[Abstract] [Full Text - PDF] [Purchase Article]

Three Component Seismogram Analysis: A Case Study of the M ? 7.7 South Java, Indonesia Earthquake on

July 17, 2006 and Changes in Coulomb Stress and Seismicity Rate

Supardiyono, Andri Dian Nugraha, Madlazim, and Bagus Jaya Santosa

Adv. Sci. Lett. 23, 12037-12042 (2017)

[Abstract] [Full Text - PDF] [Purchase Article]

Experimental Design Skills Improvement in Earth and Space Sciences Learning by

Implementing Four

Question Strategy

Supriyono and Madlazim

Adv. Sci. Lett. 23, 12043-12046 (2017)

[Abstract] [Full Text - PDF] [Purchase Article]

Formulating Variation of Strategy for Reducing Burden of Chemistry Students'

Misconceptions Based on

Conceptual Change Strategy and Individual Characteristic

Suyono, Masriyah, and Muchlis

Adv. Sci. Lett. 23, 12047-12053 (2017)

[Abstract] [Full Text - PDF] [Purchase Article]

Content of Heavy Metals (Pb, Cd, and Se) on Agricultural Land Contaminated Hot Mud Porong and the

Impact on Safety of Agricultural Product

Tarzan Purnomo and Soegiyanto

Adv. Sci. Lett. 23, 12054-12057 (2017)

[Abstract] [Full Text - PDF] [Purchase Article]

Reasoning Processes of Prospective Teachers in Proving Theorem Regarding Differences in Mathematical Ability

Susanah, I. Ketut Budayasa, Tatag Yuli Eko Siswono, and Mega Teguh Budiarto

Adv. Sci. Lett. 23, 12058-12063 (2017)

[Abstract] [Full Text - PDF] [Purchase Article]

Rapid Determination of Earthquake Magnitude Using Measurements of the Dominant Period of P-Waves

Observed at Local Stations in North Sulawesi

Tjipto Prastowo, DyahAyu Puspitasari, La Ode Ngkoimani, and La Ode Safiuddin

Adv. Sci. Lett. 23, 12064-12067 (2017) 


\section{[Abstract] [Full Text - PDF] [Purchase Article]}

Cognitive Process Analysis of PISA, TIMSS, and UN Science Items Based on Revised Bloom Taxonomy Wasis, Sukarmin, and Muji Sri Prastiwi Adv. Sci. Lett. 23, 12068-12072 (2017)

[Abstract] [Full Text - PDF] [Purchase Article]

The Specific Species Pattern of Earthworms in Contamined Area with Heavy Metals Widowati Budijastuti, Sucipto Hariyanto, and Agoes Soegianto

Adv. Sci. Lett. 23, 12073-12078 (2017)

[Abstract] [Full Text - PDF] [Purchase Article]

Development of Business Competencies Based on Entrepreneurship in the Area of Urban Sprawl

Ni Nyoman Aryaningsih, Made. Marsa Arsana, and Ketut Irianto

Adv. Sci. Lett. 23, 12079-12083 (2017)

[Abstract] [Full Text - PDF] [Purchase Article]

The Power of Hybrid Value Integration in Sustainable Tourism Development the Case of Tourism in Bali

I. Ketut Budarma and Ni Made Rai Erawati

Adv. Sci. Lett. 23, 12084-12088 (2017)

[Abstract] [Full Text - PDF] [Purchase Article]

Knowledge Management System as Transfer Media in Balinese Handicraft SMEs

I. Wayan Budi Sentana and Ni Luh Ayu Kartika Yuniastari

Adv. Sci. Lett. 23, 12089-12093 (2017)

[Abstract] [Full Text - PDF] [Purchase Article]

Approach Temperature of Heating Process in Double Tube Heat Exchanger with $\mathrm{Al}_{2} \mathrm{O}_{3}$-Water Nanofluid

Daud Simon Anakottapary, Ahmad Wibolo, Putu Wijaya Sunu, and I. Made Rajendra

Adv. Sci. Lett. 23, 12094-12097 (2017)

[Abstract] [Full Text - PDF] [Purchase Article]

Developing Green Tourism Model: A Case Study of "Cultic" at Belimbing Village, BaliIndonesia

I. Dewa M. C. Santosa, I. Putu Astawa, IN. G. Suta Waisnawa, I. Putu M. Astawa, I. Wayan Temaja, and Lilik Sudiajeng

Adv. Sci. Lett. 23, 12098-12102 (2017)

[Abstract] [Full Text - PDF] [Purchase Article]

Preferred E-Marketing Methods in Travel Bureau Operation: In Support to CommunityBased Tourism

Ni Made Ernawati and Ni Made Sudarmini 
Adv. Sci. Lett. 23, 12103-12108 (2017)

[Abstract] [Full Text - PDF] [Purchase Article]

Negotiating Between Authenticity and Change in Community-Based Tourism: Evidence from Bali

Ni Made Ernawati, Ni Gst Nym Suci Murni, and Wayan Jendra

Adv. Sci. Lett. 23, 12109-12115 (2017)

[Abstract] [Full Text - PDF] [Purchase Article]

The Benefits of Improved Aspects of Human Physiology in the Learning Process

I. Ketut Widana and I. Ketut Sudiartha

Adv. Sci. Lett. 23, 12116-12120 (2017)

[Abstract] [Full Text - PDF] [Purchase Article]

Development of Practice Set of Fares and Ticketing 3 Subject Based on Simulation with Abacus/Sabre Emulator

I. Made Budiasa and I. Ketut Suparta

Adv. Sci. Lett. 23, 12121-12126 (2017)

[Abstract] [Full Text - PDF] [Purchase Article]

Effect of Pragmatic-Based Learning Model on Students' Pragmatic Competence

I. Made Rai Jaya Widanta, Made Budiarsa, I. Wayan Simpen, and I. Made Netra

Adv. Sci. Lett. 23, 12127-12131 (2017)

[Abstract] [Full Text - PDF] [Purchase Article]

Android Based Face Recognition System Using PCA and Eigen Face

I. Nyoman Gede Arya Astawa, I. Gusti Agung Made Sunaya, and I. Gusti Ngurah Bagus Catur Bawa

Adv. Sci. Lett. 23, 12132-12135 (2017)

[Abstract] [Full Text - PDF] [Purchase Article]

Strength Analysis of Seririt Market Building Structure After the Fire

I. Wayan Suasira, I. Made Anom Santiana, W. D. Lokantara, I. Made Tapa Yasa, and I. Gede Sastra Wibawa

Adv. Sci. Lett. 23, 12136-12140 (2017)

[Abstract] [Full Text - PDF] [Purchase Article]

The Influence of Quantum Writing Method on Academic Writing Skill

Ida Bagus Artha Adnyana and Kadek Dwi Cahaya Putra

Adv. Sci. Lett. 23, 12141-12146 (2017)

[Abstract] [Full Text - PDF] [Purchase Article]

Strategic Information Systems Planning at Bali State Polytechnic Using Ward and Peppard Framework

Kadek Cahya Dewi and Putu Adi Suprapto

Adv. Sci. Lett. 23, 12147-12151 (2017) 


\section{[Abstract] [Full Text - PDF] [Purchase Article]}

The Prediction of Transitive Derivative Verbs -kan and -i Suffixs in Indonesian (Linguistic Typology Study)

Lien Darlina and Ketut Artawa

Adv. Sci. Lett. 23, 12152-12155 (2017)

[Abstract] [Full Text - PDF] [Purchase Article]

Recharge Wells Innovation for Domestic Rainwater Harvesting

Lilik Sudiajeng, I. Wayan Wiraga, I. Gusti Lanang Parwita, and Made Mudhina

Adv. Sci. Lett. 23, 12156-12160 (2017)

[Abstract] [Full Text - PDF] [Purchase Article]

Assessment and Evaluation on the Aquifer in Denpasar City

Lilik Sudiajeng, Made Mudina, Made Sudiarsa, Made Tapayasa, and Wayan Suparta

Adv. Sci. Lett. 23, 12161-12167 (2017)

[Abstract] [Full Text - PDF] [Purchase Article]

The Application of Interactive Multimedia Technologies in the Development of Instructional Media for

Practice of Mechanical Technology

I. Made Rajendra, Ida Ayu Anom Arsani, and I. Made Sudana

Adv. Sci. Lett. 23, 12168-12171 (2017)

[Abstract] [․ㅏll Text - PDF] [Purchase Article]

Social and Speech Community of Central Java Indonesia

Majid Wajdi and Paulus Subiyanto

Adv. Sci. Lett. 23, 12172-12176 (2017)

[Abstract] [Full Text - PDF] [Purchase Article]

Corporate Social Responsibility Based on Tri Hita Karana: The Implementation in the Hotel Industry

Nyoman Indah Kusuma Dewi, I. Gusti Agung Bagus Mataram, and I. Wayan Siwantara

Adv. Sci. Lett. 23, 12177-12181 (2017)

[Abstract] [Full Text - PDF] [Purchase Article]

Ergonomic Chair Design for Nursing Mothers to Increase Motivation of Exclusive Breastfeeding

I. Nyoman Sutapa, I. Made Anom Santiana, M. Yusuf, and W. D. Lokantara

Adv. Sci. Lett. 23, 12182-12185 (2017)

[Abstract] [Full Text - PDF] [Purchase Article]

Text Processing Application for Indonesian Documents

Putu Manik Prihatini and I. Ketut Suryawan

Adv. Sci. Lett. 23, 12186-12189 (2017)

[Abstract] [Full Text - PDF] [Purchase Article] 
Experimental Investigations of Heat Transfer Enhancement in a Double Tube Heat

Exchanger with

Rectangular Grooved

Putu Wijaya Sunu, I. Nyoman Sutarna, and I. Made Arsawan

Adv. Sci. Lett. 23, 12190-12193 (2017)

[Abstract] [Full Text - PDF] [Purchase Article]

The Characteristics of Pressure Drop in a Grooved Annulus of Double Pipe Heat Exchanger Putu Wijaya Sunu and I. Made Rasta

Adv. Sci. Lett. 23, 12194-12197 (2017)

[Abstract] [Full Text - PDF] [Purchase Article]

Social Influence and Energy Conservation: Using Obedience to Authority to Promote Air

Conditioning

Energy Saving

Wayan G. Santika, I. Ketut Gede Sudiartha, and I. Made Widiantara

Adv. Sci. Lett. 23, 12198-12201 (2017)

[Abstract] [Full Text - PDF] [Purchase Article]

The Role of Condenser Approach Temperature on Energy Conservation of Water Cooled Chiller

I. Nyoman Suamir, I. Nyoman Gede Baliarta, Made Ery Arsana, and I. Wayan Temaja

Adv. Sci. Lett. 23, 12202-12205 (2017)

[Abstract] [Full Text - PDF] [Purchase Article]

Waste Heat Recovery from Central AC System for Hot Water Supply; A Case Study for Hotel Building

Application in Indonesia

I. Nyoman Suamir, I. Nengah Ardita, and I. Gusti Agung Bagus Wirajati

Adv. Sci. Lett. 23, 12206-12210 (2017)

[Abstract] [Full Text - PDF] [Purchase Article]

Marginalization of Local Community in Tourism Area of Nusa Dua Bali

N. G. N. Suci Murni, I. Putu Astawa, and I. K. Budarma

Adv. Sci. Lett. 23, 12211-12214 (2017)

[Abstract] [Full Text - PDF] [Purchase Article]

Partnership Strategy for Competing Globally

Ni Wayan Sukartini, Ni Ketut Lasmini, and Ni Made Sudarmini

Adv. Sci. Lett. 23, 12215-12219 (2017)

[Abstract] [Full Text - PDF] [Purchase Article]

The Empowerment Model of the Underdeveloped Regions Society Through the Innovation of Cattle-Fattening

Soedarto Teguh, Syaifuddin Zuhri, Soemartono, and Ertien Rining

Adv. Sci. Lett. 23, 12220-12222 (2017) 


\section{[Abstract] [Full Text - PDF] [Purchase Article]}

Isolation and Analysis of Sucrose Synthase (SUS) Gene Fragment Originated from "Kopyor" Coconut Mutant

Sukendah, Hugo Volkaerd, and Sudarsono

Adv. Sci. Lett. 23, 12223-12226 (2017)

[Abstract] [Full Text - PDF] [Purchase Article]

Hay and Silage: Two Effective Ways of Animal Feed Ingredients Preservation for the Underdeveloped

Rural Societies

Soedarto Teguh, Syaifuddin Zuhri, Soemartono, and Ertien Rining

Adv. Sci. Lett. 23, 12227-12230 (2017)

[Abstract] [Full Text - PDF] [Purchase Article]

Influence of Citric Acid on Struvite Precipitation

Dyah Suci Perwitasari, J. Jamari, Stefanus Muryanto, and Athanasius P. Bayuseno

Adv. Sci. Lett. 23, 12231-12234 (2017)

[Abstract] [Full Text - PDF] [Purchase Article]

Hydrolysis of Cellulose from Bamboo with Biology Process Using Enzyme

Sari Ni Ketut, Yonathan Nico, Lestari Tika, and Ernawati Dira

Adv. Sci. Lett. 23, 12235-12238 (2017)

[Abstract] [Full Text - PDF] [Purchase Article]

The Effect of Heating Temperature at the Bleaching Process of Palm Oil to the Color's

Absorption of

Activated-Based Trass Rock

Laurentius Urip Widodo, Sukirmiyadi, and Kindriari Nurma Wahyusi

Adv. Sci. Lett. 23, 12239-12242 (2017)

[Abstract] [Full Text - PDF] [Purchase Article]

Scale Formation of Barium Sulfate in the Piping Flow System: Mineralogy and Morphology Evaluation

N. Karaman, J. Jamari, A. P. Bayuseno, and S. Muryanto

Adv. Sci. Lett. 23, 12243-12246 (2017)

[Abstract] [Full Text - PDF] [Purchase Article]

Formation and Controlling of Struvite Crystals Using a Novel-Vertical Reactor: Study on

Purity and

Morphology Variation

L. Edahwati, S. Sutiyono, S. Muryanto, J. Jamari, and A. P. Bayuseno

Adv. Sci. Lett. 23, 12247-12251 (2017)

[Abstract] [Full Text - PDF] [Purchase Article]

A Chemical Effectivity Study on Removal of Seawater $\mathrm{Mg}^{2+}, \mathrm{K}^{+}, \mathrm{Ca}^{2+}$ and $\mathrm{SO}_{4}{ }^{2-} \mathrm{Ions}^{2}$ 
Caecillia Pujiastuti, Yustina Ngatilah, Ketut Sumada, and Srie Muljani

Adv. Sci. Lett. 23, 12252-12255 (2017)

[Abstract] [Full Text - PDF] [Purchase Article]

Gas Purification in Coal Pyrolisis Used the Catalyst $\mathrm{Ca}(\mathrm{OH}) 2: \mathrm{CH} 3 \mathrm{ONa}$

Sukamto, Didi Samanhudi, Sunardi, and Nana Dyah Siswati

Adv. Sci. Lett. 23, 12256-12258 (2017)

[Abstract] [Full Text - PDF] [Purchase Article]

Characterization of Zeolite as an Adsorbent for Capturing $\mathbf{C O}_{2}$

Isni Utami, Sri Redjeki, Dwi Hery Astuti, and Nurul Widji Triana

Adv. Sci. Lett. 23, 12259-12262 (2017)

[Abstract] [Full Text - PDF] [Purchase Article]

Use of Upflow Fluidized Bed Reactor (FBR) for Recovery Phosphorus from Waste-Water Through

Struvite Precipitation

Sutiyono, L. Edahwati, S. Muryanto, J. Jamari, and A. P. Bayuseno

Adv. Sci. Lett. 23, 12263-12267 (2017)

[Abstract] [Full Text - PDF] [Purchase Article]

Antibacterial Activity of Leucaena leucocephala Extracts on Growth of Escherichia coli D. F. Rosida, S. Djajati, Z. A. Nilamayu, and Rosida

Adv. Sci. Lett. 23, 12268-12271 (2017)

[Abstract] [Full Text - PDF] [Purchase Article]

Physical Characteristics of Fish Bone Gelatin Extracted Acid

N. Hapsari, D. F. Rosida, S. Djajati, A. Aviskarahman, R. Dewati, and Sudaryati

Adv. Sci. Lett. 23, 12272-12275 (2017)

[Abstract] [Full Text - PDF] [Purchase Article]

Identification of Pedada Fibers by Fourier Transform Infrared Spectrophotometer (FTIR) Jariyah, Simon Bambang Widjanarko, Yunianta, and Teti Estiasih

Adv. Sci. Lett. 23, 12276-12278 (2017)

[Abstract] [Full Text - PDF] [Purchase Article]

The Search of Meaning of Today's Alun-Alun Malang (Through Pierce's Semiotic Reading) Wiwik Dwi Susanti and Dyan Agustin

Adv. Sci. Lett. 23, 12279-12285 (2017)

[Abstract] [Full Text - PDF] [Purchase Article]

The Sense of Place of Home Based Enterprises at the Metal Kampung of Pandean Muchlisiniyati Safeyah, Eva Elviana, and Aris Sutejo

Adv. Sci. Lett. 23, 12286-12289 (2017)

[Abstract] [Full Text - PDF] [Purchase Article] 
Design Study of Shared Kitchen with Social Interaction in Vertical Housing Dyan Agustin and Wiwik Dwi Susanti

Adv. Sci. Lett. 23, 12290-12294 (2017)

[Abstract] [Full Text - PDF] [Purchase Article]

Road Damage Analysis of Kalianak Road Surabaya

Sholichin Ibnu and Utomo Nugroho

Adv. Sci. Lett. 23, 12295-12299 (2017)

[Abstract] [Full Text - PDF] [Purchase Article]

Optimization of the Used of Public Open Space in Low Income Residential Areas

Eva Elviana, Sri Suryani, and Wiwik Dwi Susanti

Adv. Sci. Lett. 23, 12300-12303 (2017)

[Abstract] [Full Text - PDF] [Purchase Article]

Orientation Optimization of Flat Building in Humid Tropical Climate: Case Study on UPN Veteran East

Java's Apartment

Heru Subiyantoro and Erwin Djuni Winarto

Adv. Sci. Lett. 23, 12304-12308 (2017)

[Abstract] [․ㅏll Text - PDF] [Purchase Article]

Information System Audit Based on Customer Perspective 4

Siti Mukaromah and Apol Pribadi

Adv. Sci. Lett. 23, 12309-12312 (2017)

[Abstract] [Full Text - PDF] [Purchase Article]

Analysis of Cocoa Production in Smallholder Plantations to Increase Productivity Using System

Dynamics Approach

Syurfah Ayu Ithriah, Erma Suryani, and Isnaini Muhandis

Adv. Sci. Lett. 23, 12313-12317 (2017)

[Abstract] [Full Text - PDF] [Purchase Article]

Comparison of Production Glucose from Starch and Cellulose Using Delignification and Hydrolysis Process

Sari Ni Ketut, C. Pudjiastuti, and Ketut Sumada

Adv. Sci. Lett. 23, 12318-12321 (2017)

[Abstract] [Full Text - PDF] [Purchase Article]

Comparative Analysis Using Cavitation and No-Cavitation Models for Lubricated Journal Bearing: A Study

Case of Effect of Radial Velocity

S. Susilowati, Brain Choirul Ichsan, Mohammad Tauviqirrahman, Jamari, A. P. Bayseno, and Muchammad

Adv. Sci. Lett. 23, 12322-12324 (2017) 


\section{[Abstract] [Full Text - PDF] [Purchase Article]}

Geometrical Analysis of Artificial Rough Surfaces: Mathematical and CAD Model Kartini, G. A. Sipayung, E. Saputra, R. Ismail, J. Jamari, and A. P. Bayuseno Adv. Sci. Lett. 23, 12325-12329 (2017) [Abstract] [Full Text - PDF] [Purchase Article]

Building Accountability in Religious Organization Through Accounting Changes Indrawati Yuhertiana, Gideon Setyo Budiwitjaksono, and Ignatia Martha Hendarti Adv. Sci. Lett. 23, 12330-12332 (2017) [Abstract] [Full Text - PDF] [Purchase Article]

Identification of Chlorophyll-A Distribution Using Landsat 8 in Madura Rosida Vivin Nahari and Riza Alfita Adv. Sci. Lett. 23, 12333-12335 (2017) [Abstract] [Full Text - PDF] [Purchase Article]

Health of Dental and Mouth Based on Forward Chaining Method Muhammad Ali Syakur and Devie Rosa Anamisa Adv. Sci. Lett. 23, 12336-12339 (2017) [Abstract] [Full Text - PDF] [Purchase Article]

Forecasting Application for Simpati Telkomsel Card Using Backpropagation (Case Study in Bangkalan Madura-Indonesia)

Eka Mala Sari Rochman and Aeri Rachmad

Adv. Sci. Lett. 23, 12340-12343 (2017)

[Abstract] [Full Text - PDF] [Purchase Article]

Voice Recognition Application by Using Fisher's Linear Discriminant Analysis (FLDA) Feature Extraction

Aeri Rachmad, Devie Rosa Anamisa, and Novia Putri Bintari

Adv. Sci. Lett. 23, 12344-12348 (2017)

[Abstract] [Full Text - PDF] [Purchase Article]

Face Recognition Based on Gender Using a Modified Method of 2D-Linear Discriminant Analysis

Fitri Damayanti, Wahyudi Setiawan, Sri Herawati, and Aeri Rachmad

Adv. Sci. Lett. 23, 12349-12353 (2017)

[Abstract] [Full Text - PDF] [Purchase Article]

Generation of Frequent Itemset Using Fuzzy Weighted Tree with Cosine Similarity Budi Dwi Satoto

Adv. Sci. Lett. 23, 12354-12358 (2017)

[Abstract] [Full Text - PDF] [Purchase Article]

Lung Cancer Nodule Location Diagnoses Using Linear Vector Quantization Based on 
Morphology Process

Haryanto, Achmad Fiqhi Ibadillah, Kunto Aji, Puput Wanarti Rusimamto, and Lilik Anifah Adv. Sci. Lett. 23, 12359-12361 (2017)

[Abstract] [Full Text - PDF] [Purchase Article]

Information Technology Governance: A Cross Comparison in Public and Private Sectors Wahyudi Agustiono

Adv. Sci. Lett. 23, 12362-12366 (2017)

[Abstract] [Full Text - PDF] [Purchase Article]

Integration in Electronic Data Interchange for Environments E-Commerce Application Bain Khusnul Khotimah, Yoga Dwitya Pramudita, and Muhammad Ali Syakur

Adv. Sci. Lett. 23, 12367-12371 (2017)

[Abstract] [Full Text - PDF] [Purchase Article]

An Ergonomic Intervention Model by Sampling Inspection and Personal Protective Equipment in SMEs Batik Madura

Fitri Agustina, Nachnul Ansori, and Yuliatin

Adv. Sci. Lett. 23, 12372-12376 (2017)

[Abstract] [Full Text - PDF] [Purchase Article]

Scheduling of the Certification Process with the Selection of Employees to Minimize the Completion Time

Using Differential Evolution Algorithm

IkaDeefi Anna and Badrud Tamam

Adv. Sci. Lett. 23, 12377-12380 (2017)

[Abstract] [Full Text - PDF] [Purchase Article]

Decision Making of Warehouse Location Selection Using Brown-Gibson Model

Ari Basuki and Andharini Dwi Cahyani

Adv. Sci. Lett. 23, 12381-12384 (2017)

[Abstract] [Full Text - PDF] [Purchase Article]

Influence of Knowledge Transfer Effectiveness on Enterprise Resource Planning System Success in

Indonesian Medium-Sized Enterprises

Indra Cahyadi

Adv. Sci. Lett. 23, 12385-12388 (2017)

[Abstract] [Full Text - PDF] [Purchase Article]

Modeling of Air Polluter Standard Index Based on Geographically Weighted Regression Approach Using

Adaptive Bandwidth

Kukuh Winarso and Hasbi Yasin

Adv. Sci. Lett. 23, 12389-12392 (2017)

[Abstract] [Full Text - PDF] [Purchase Article] 
Vehicle Routing Problem Settlement for Supply Chain Network of Batik SMEs in Pamekasan District Area

Sabarudin Akhmad

Adv. Sci. Lett. 23, 12393-12395 (2017)

[Abstract] [Full Text - PDF] [Purchase Article]

Design Controller Blade Pitch Angle Wind Turbine Using Hybrid Differential Evolution

Algorithm-Particle

Swarm Optimization

Miftachul Ulum, Herlambang Setiadi, and Dwi Lastomo

Adv. Sci. Lett. 23, 12396-12399 (2017)

[Abstract] [Full Text - PDF] [Purchase Article]

Android Base Mobile Banking Security Systems Using the 13 CODIS Deoxyribonucleic Acid (DNA) Verification

Diana Rahmawati, Oktriza Melfazen, and Khairul Umam

Adv. Sci. Lett. 23, 12400-12404 (2017)

[Abstract] [Full Text - PDF] [Purchase Article]

Enhancement of Forecasting Value with Quadratic Equation Method on Computer Network Performance

Achmad Ubaidillah and S. Ida Kholida

Adv. Sci. Lett. 23, 12405-12408 (2017)

[Abstract] [Full Text - PDF] [Purchase Article]

Feature Extraction and Classification Method for Identification of Batik Cloth

Mulaab

Adv. Sci. Lett. 23, 12409-12412 (2017)

[Abstract] [Full Text - PDF] [Purchase Article]

Crude Oil Price Forecasting Using Ensemble Empirical Mode Decomposition and Generalized Regression

Neural Networks

Sri Herawati and M. Latif

Adv. Sci. Lett. 23, 12413-12416 (2017)

[Abstract] [Full Text - PDF] [Purchase Article]

The Control of Home Appliances Using Voice Command Based on Speech Recognition M. Latif, Achmad Dafid, Vivi Tri Widyaningrum, Ahmad Sahru Romadhon, and Sri Wahyuni Adv. Sci. Lett. 23, 12417-12419 (2017)

[Abstract] [Full Text - PDF] [Purchase Article]

Pattern Recognition Letters and Numbers Handwriting by Using Backpropagation and Genetic Algorithms Methods

Ahmad Sahru Romadhon and Hairil Budiarto

Adv. Sci. Lett. 23, 12420-12423 (2017) 


\section{[Abstract] [Full Text - PDF] [Purchase Article]}

Determining Best Congestion Threshold Value on Congestion Avoidance Ad Hoc on Demand Distance Vector

Reliable Delivery Routing Protocol

Ach Khozaimi and Ika Oktavia Suzanti

Adv. Sci. Lett. 23, 12424-12427 (2017)

[Abstract] [Full Text - PDF] [Purchase Article]

Design of Badminton Matches Statistics Center for Monitoring Badminton Players Performances

Sigit Susanto Putro and Yoga Dwitya Pramudita

Adv. Sci. Lett. 23, 12428-12431 (2017)

[Abstract] [Full Text - PDF] [Purchase Article]

Optimalization of Detection and Navigation Smart Bin Robot Using Camera

Faikul Umam

Adv. Sci. Lett. 23, 12432-12436 (2017)

[Abstract] [Full Text - PDF] [Purchase Article]

Design of Risk Assessment for Small and Medium Sized Enterprises of Batik Madura Issa Dyah Utami

Adv. Sci. Lett. 23, 12437-12439 (2017)

[Abstract] [Full Text - PDF] [Purchase Article]

\section{A SPECIAL SECTION}

Selected Peer-Reviewed Articles from the International Conference on Health, Pharmacy and Medicine

(ICHPM2017), Johor Bahru, Malaysia, 26-27 October, 2017

Guest Editors: Dyah Aryani Perwitasari, Sabtanti Harimurti, Muhammad Da’i, Didik Setiawan, Wiwik Kusumawati,

Nunuk Aries Nurulita, and Abdul Azis Alimul Hidayat

Adv. Sci. Lett. 23, 12440-12442 (2017)

[Abstract] [Full Text - PDF] [Purchase Article]

\section{RESEARCH ARTICLES}

Antimicrobial Activity of Lime Juice (Citrus aurantifolia) Against Propionibacterium acnes and

Staphylococcus epidermidis

Nur Aini, Bella Permatasani, Umi Khasanah, and Anita Sukmawati

Adv. Sci. Lett. 23, 12443-12446 (2017)

[Abstract] [Full Text - PDF] [Purchase Article]

Determination of Captopril in Rat Plasma by LC-MS/MS in Presence of Apigenin Siska, Franciscus D. Suyatna, Abdul Mun'im, Anton Bahtiar, and Priyanto

Adv. Sci. Lett. 23, 12447-12450 (2017) 


\section{[Abstract] [Full Text - PDF] [Purchase Article]}

Effect of Temulawak (Curcuma xanthorrhiza Roxb.) Extract on the MDA Levels and GPx Activity in the

Brains of Trimethyltin Induced Dementia Model Rats

Sapto Yuliani, Didik Yuni Prasetya, and Moch. Saiful Bachri

Adv. Sci. Lett. 23, 12451-12454 (2017)

[Abstract] [Full Text - PDF] [Purchase Article]

The Effect of Inoculum Concentration on the Growth Profile and Antibacterial Activity of Actinomycete

(A6K) Isolates

Ika Maylani Ningsih and Nanik Sulistyani

Adv. Sci. Lett. 23, 12455-12458 (2017)

[Abstract] [Full Text - PDF] [Purchase Article]

Diabetes Distress Scale and Treatment Outcome: Perspectives of Clinical and Psychometric Outcome in

Diabetic Patients

Dyah Aryani Perwitasari, Mentari Yulistika, Imaniar Noor Faridah, and Yusuf Kulle

Adv. Sci. Lett. 23, 12459-12463 (2017)

[Abstract] [Full Text - PDF] [Purchase Article]

Perception, HbA1c and the Quality of Life of Diabetes Mellitus (T2DM) Patients at RSUD Abdul Azis Singkawang

Imaniar Noor Faridah, Nurul Masyithah, and Dyah Aryani Perwitasari

Adv. Sci. Lett. 23, 12464-12468 (2017)

[Abstract] [Full Text - PDF] [Purchase Article]

Risk Factors for Multidrug Resistant (MDR) in Tuberculosis Patients at Public Hospitals in Indonesia

Hidayah Karuniawati, Tanti Azizah Sudjono, Harningtyas Nindya Utami, and Rengganis Ajeng

Pangastuti

Adv. Sci. Lett. 23, 12469-12473 (2017)

[Abstract] [Full Text - PDF] [Purchase Article]

The Direct Medical Cost of Diabetes Mellitus Type 2 Therapy on Inpatients of Hospital X Indonesia

Faridah Baroroh and Qarriy 'Aina Urfiyya

Adv. Sci. Lett. 23, 12474-12477 (2017)

[Abstract] [Full Text - PDF] [Purchase Article]

Nigella Sativa (Black Seeds) Oil Adjuvant Therapy Decrease on SGOT Activity in Patients at Risk of Metabolic

Syndrome Receiving Standard Therapy

Endang Darmawan, Akrom, and Desi Reski Fajar 
Adv. Sci. Lett. 23, 12478-12481 (2017)

[Abstract] [Full Text - PDF] [Purchase Article]

Cost Effectiveness Analysis of Type-2 Antidiabetic Drugs in PKU Muhammadiyah Yogyakarta Hospital, Indonesia

P. Pertiwi, D. Setiawan, and D. A. Perwitasari

Adv. Sci. Lett. 23, 12482-12485 (2017)

[Abstract] [Full Text - PDF] [Purchase Article]

Characterization of Chitosan Nanoparticle Containing Combination Doxorubicin and Curcumin Analogue

Anita Sukmawati, Muhammad Da 'i, Ratna Yuliani, Safitri N. Anggraeni, and Diah Wahyuningsih Adv. Sci. Lett. 23, 12486-12488 (2017)

[Abstract] [Full Text - PDF] [Purchase Article]

Antioxidant Effect of Purple Yam Lipstick

Anjar Mahardian Kusuma, Susmiyatun, and Indri Hapsari

Adv. Sci. Lett. 23, 12489-12492 (2017)

[Abstract] [Full Text - PDF] [Purchase Article]

The Extract of Yellow Pumpkins Seed (Cucurbita moschata) Induces Morphological Change in Endometrial

Glands of Ovariectomized Rats

Alfaina Wahyuni and Sri Tasminatun

Adv. Sci. Lett. 23, 12493-12497 (2017)

[Abstract] [Full Text - PDF] [Purchase Article]

Optimization of Anti-Cancer Gamavuton-0 Synthesis Using Box Behnken Experimental Design

Sabtanti Harimurti, Hari Widada, Sri Kadarinah, Ismanurrahman Hadi, Didy Putra Wijaya, Komarudin, and

Maulana Akbar Rifai

Adv. Sci. Lett. 23, 12498-12501 (2017)

[Abstract] [Full Text - PDF] [Purchase Article]

Preparation and Antioxidant Activity of Cosmeceutical Creams Containing Spirulina platensis and Zinc

Oxide Nanoparticles

Erindyah Retno Wikantyasning, Muhammad Da'i, Agung Beny Santosa, and Devy Anwar Zhelsiana Adv. Sci. Lett. 23, 12502-12505 (2017)

[Abstract] [Full Text - PDF] [Purchase Article]

Effect of Increasing Concentrations of Tween 80 and Sorbitol as Surfactants and Cosurfactans Against the

Physical Stability Properties of Palm Oil Microemulsion

Kori Yati, Anisa Amalia, and Deby Puspasari 
Adv. Sci. Lett. 23, 12506-12509 (2017)

[Abstract] [Full Text - PDF] [Purchase Article]

Effect of Lecithin's Concentration of Entrapment Vitamin E Acetate Liposomes Using Thin Layers Hydration Method

Ari Widayanti, Rahmah Elfiyani, and Dewi Lestari

Adv. Sci. Lett. 23, 12510-12513 (2017)

[Abstract] [Full Text - PDF] [Purchase Article]

Anti-Inflammatory Activity of Cream Type O/W with Concentration Variation of Essential Oils of Clove

(Syzigium aromaticum)

Nining Sugihartini, Aina Fatkhil Haque, and Tedjo Yuwono

Adv. Sci. Lett. 23, 12514-12517 (2017)

[Abstract] [Full Text - PDF] [Purchase Article]

Correlation Between Nurses' Job Satisfaction and Motivation, and Nurses' Performance in Indonesia:

A Cross Sectional Study in Soewandi Hospital

Abdul Aziz Alimul Hidayat, Sukadiono, Ratna Agustin, and Ike Sugiarti Ningsih

Adv. Sci. Lett. 23, 12518-12520 (2017)

[Abstract] [Full Text - PDF] [Purchase Article]

Objective Structure Clinical Examination (OSCE) Based Teaching Material Development Musrifatul Uliyah and Abdul Aziz Alimul Hidayat

Adv. Sci. Lett. 23, 12521-12523 (2017)

[Abstract] [Full Text - PDF] [Purchase Article]

Residential Area as a Contributing Factor to Basal Cell Carcinoma Incidence in Madura Island, Indonesia

Nova Primadina

Adv. Sci. Lett. 23, 12524-12527 (2017)

[Abstract] [Full Text - PDF] [Purchase Article]

Comparison of Energy, Protein, and Iodine Intake of Women of Childbearing Age with

Euthyroidism and

Hyperthyroidism in Endemic Iodine Deficiency Area

Mutalazimah and Setia Asyanti

Adv. Sci. Lett. 23, 12528-12531 (2017)

[Abstract] [Full Text - PDF] [Purchase Article]

The Relationship Between Dietary Knowledge and Glycemic Control in Patient with Diabetes Type 2:

A Comunity-Based, Cross-Sectional Study

Fahrun Nur Rosyid, Supratman, Tomy Adi Prasetyo, Desiana Dwi Astutik, Kinasih Bayu Nurseto, and 
Uswatun Hasanah Widyaningtyas

Adv. Sci. Lett. 23, 12532-12535 (2017)

[Abstract] [Full Text - PDF] [Purchase Article]

Relationship Between Social Support and Health-Related Quality of Life of Hypertensive Women in Indonesia

Supratman, Fahrun Nur Rosyid, and Tomy Ady Prasetyo

Adv. Sci. Lett. 23, 12536-12539 (2017)

[Abstract] [Full Text - PDF] [Purchase Article]

Social Support Approach: Development of Nursing Holistic Care Model in Surabaya

Pipit Festi and Anas Tamsuri

Adv. Sci. Lett. 23, 12540-12545 (2017)

[Abstract] [Full Text - PDF] [Purchase Article]

Faster Learning Organization (FLO) Model of Transform Strategy Group to Enhance Holistic Nurses Skills

Mundakir

Adv. Sci. Lett. 23, 12546-12549 (2017)

[Abstract] [Full Text - PDF] [Purchase Article]

Factors Associated with the Nurse Compliance in Nursing Round Implementation at Siti Khodjijah Hospital

Dede Nasrullah, Sri Rejeki, and Fitria Handayani

Adv. Sci. Lett. 23, 12550-12554 (2017)

[Abstract] [Full Text - PDF] [Purchase Article]

The Influence of Audiovisual Media with Dick and Carey Model of Learning Skill Subject on Student's

Learning Achievement in the Faculty of Medicine

N. Juni Triastuti

Adv. Sci. Lett. 23, 12555-12558 (2017)

[Abstract] [Full Text - PDF] [Purchase Article]

Modification of the Psychiatric Emergency Patient Acuity Tool Within a Triage System in an Emergency Unit

Arum Pratiwi, Arief Wahyudi Jadmiko, and Arif Widodo

Adv. Sci. Lett. 23, 12559-12562 (2017)

[Abstract] [Full Text - PDF] [Purchase Article]

Level of Family Knowledge on Diabetes Mellitus Diet in Yogyakarta

Fahni Haris and Aulia Ayu Nugraheni

Adv. Sci. Lett. 23, 12563-12567 (2017)

[Abstract] [Full Text - PDF] [Purchase Article]

Correlation Between Incentives and Nurses' Job Satisfaction in Indonesia: A Cross Sectional 
Study in Surabaya

Husada Utama Hospital

Sukadiono, Ratna Agustin, Abdul Aziz Alimul Hidayat, and Annisah Ulfa Hanif

Adv. Sci. Lett. 23, 12568-12570 (2017)

[Abstract] [Full Text - PDF] [Purchase Article]

The Correlation Between Infant Temperament and Sleep Quality of Postpartum Mother in Primary Health

Care Prambanan and Jogonalan Klaten Indonesia

Yuni Astuti, Imami Nur Rachmawati, and Hayuni Rahma

Adv. Sci. Lett. 23, 12571-12574 (2017)

[Abstract] [Full Text - PDF] [Purchase Article]

The Innovation of Artrihpi Irrigation Wound Cleansing for Decreasing Bacterial Load in the Treatment Diabetic

Foot Ulcers: Randomized Controlled Trial

Resti Yulianti Sutrisno, Dewi Gayatri, and Agung Waluyo

Adv. Sci. Lett. 23, 12575-12579 (2017)

[Abstract] [Full Text - PDF] [Purchase Article]

The Correlation Between Demographic Data of Kaders' to Health Locus of Control Score and the Opinion About

Mental Health Services in Indonesia

Shanti Wardaningsih and Takayuki Kageyama

Adv. Sci. Lett. 23, 12580-12583 (2017)

[Abstract] [Full Text - PDF] [Purchase Article]

The Effect of Waste Management Training on Entrepreneurship Motivation

Surahma Asti Mulasari and Fatwa Tentama

Adv. Sci. Lett. 23, 12584-12588 (2017)

[Abstract] [Full Text - PDF] [Purchase Article]

Validation of the Breast Cancer Awareness Scale Indonesian (BCAS-I) in Yogyakarta, Indonesia

Solikhah Solikhah, Monthida Sangruangake, Supannee Promthet, and Cameron P. Hurst

Adv. Sci. Lett. 23, 12589-12593 (2017)

[Abstract] [Full Text - PDF] [Purchase Article]

Professional Behavior Learning by Trigger Film, Self-Reflection and Expert Panel in Medical Education

Wiwik Kusumawati, Titi S. Prihatiningsih, Gandes R. Rahayu, and Soenarto Sastrowijoto

Adv. Sci. Lett. 23, 12594-12598 (2017)

[Abstract] [Full Text - PDF] [Purchase Article]

Cognitive Therapy Model to Control the Blood Sugar Level for Diabetic Patients in a Community 
A. Muhlisin, Arum Pratiwi, and Winarsih Nurambarwati

Adv. Sci. Lett. 23, 12599-12602 (2017)

[Abstract] [Full Text - PDF] [Purchase Article]

Validity and Reliability of Caring Instrument for Emergency Department; Gadar Caring Scale (GCS-46)

Jebul Suroso

Adv. Sci. Lett. 23, 12603-12606 (2017)

[Abstract] [Full Text - PDF] [Purchase Article]

Empowerment Model of Breastfeeding Mothers in Exclusive Breast Milk Program in Yogyakarta Indonesia

Mufdlilah, Endang Sutisna, A. A. Subijanto, and Muhammad Akhyar

Adv. Sci. Lett. 23, 12607-12612 (2017)

[Abstract] [Full Text - PDF] [Purchase Article]

The Effectiveness of Walking Exercise and Yoga Training Effect Comparison to Increase Expiration Peak

Toward Sleep Quality for COPD (Respiratory) Patients in Respiratory Hospital West

Sumatera

Zuriati, Melti Suriya, Yuanita Ananda, and Novrianti Achyiar

Adv. Sci. Lett. 23, 12613-12615 (2017)

[Abstract] [․ㅏll Text - PDF] [Purchase Article]

College Students' Motivation and Willingness to Pay for Smoking Cessation Services Arlina Dewi and Dianita Sugiyo

Adv. Sci. Lett. 23, 12616-12618 (2017)

[Abstract] [Full Text - PDF] [Purchase Article]

The Effect of the Foot Care Education Program on Knowledge and Self-Efficacy Among Family of Diabetes

Mellitus Patients in PKU Muhammadiyah Gamping Yogyakarta Indonesia

Yanuar Primanda, Puput Bayu Putra, Sitti Rahma Soleman, and Wiwi Melianita Arba

Adv. Sci. Lett. 23, 12619-12622 (2017)

[Abstract] [Full Text - PDF] [Purchase Article]

Perceptions of Indonesian Practical Nurses Towards Nursing Competence: A Qualitative Study

Fitri Arofiati and Khanitta Nuntaboot

Adv. Sci. Lett. 23, 12623-12626 (2017)

[Abstract] [Full Text - PDF] [Purchase Article]

Positive Spiritual Value of Elderly Diabetics in "Rumah Peduli Diabetes Mellitus"

Dinasti Pudang Binoriang, Etty Rekawati, and Wiwin Wiarsih

Adv. Sci. Lett. 23, 12627-12630 (2017)

[Abstract] [Full Text - PDF] [Purchase Article] 
Family Support Toward Adherence of Pregnant Woman to Consume Fe Tablets in Puskesmas Gamping 2, Yogyakarta Nur Azizah Indriastuti and Rizqi Nur Alifah

Adv. Sci. Lett. 23, 12631-12635 (2017)

[Abstract] [Full Text - PDF] [Purchase Article]

Exploratory Factor Analysis of the Diabetes Self-Efficacy Scale Among Type 2 Diabetes Mellitus in Thailand

Monthida Sangruangake, Solikhah Solikhah, Chananya Jirapornkul, and Cameron Hurst

Adv. Sci. Lett. 23, 12636-12640 (2017)

[Abstract] [Full Text - PDF] [Purchase Article]

Parental Behavior Based on Parent Knowledge to Give Information About Reproduction Health to Teenagers

Dewi Puspita and Lisyah Bonita Paputungan

Adv. Sci. Lett. 23, 12641-12644 (2017)

[Abstract] [Full Text - PDF] [Purchase Article]

The Increased Knowledge of Handwashing on Elementary School Students Due to Education About

Handwashing with Donkey Bridge

Kusbaryanto and Rasikhah

Adv. Sci. Lett. 23, 12645-12647 (2017)

[Abstract] [Full Text - PDF] [Purchase Article]

The Impact of Hardiness and Social Support on Work Stress

Fatwa Tentama, Nurfitria Swastiningsih, and Subardjo

Adv. Sci. Lett. 23, 12648-12651 (2017)

[Abstract] [Full Text - PDF] [Purchase Article]

Differences in Response of Staphylococcus aureus Protein to Serum IgG and Secretion of Uterine Cervical

s-IgA from Fertile and Infertile Couples Women with Non-Specific Vaginitis

Muhammad Anas, Aulanni'am Aulanni'am, I. Wayan Arsana Wiyasa, Teguh Wahju Sardjono, and Sumarno

Adv. Sci. Lett. 23, 12652-12655 (2017)

[Abstract] [Full Text - PDF] [Purchase Article]

Gentle Introduction of Generalizability Theory Analysis in OSCE Using EduG for Medical Educators

Winny Setyonugroho

Adv. Sci. Lett. 23, 12656-12659 (2017)

[Abstract] [Full Text - PDF] [Purchase Article]

Comparison of Root Mean Square of Successive Differences (RMSSD) Among Adolescent 
Smokers and

Nonsmokers in Yogyakarta

Nurvita Risdiana

Adv. Sci. Lett. 23, 12660-12664 (2017)

[Abstract] [Full Text - PDF] [Purchase Article]

Spatial Memory in Adulthood Rat with Prenatal Hypoxia-Ischaemia

Ratna Indriawati, Soedjono Aswin, Ginus Partadiredja, and Rina Susilowati

Adv. Sci. Lett. 23, 12665-12669 (2017)

[Abstract] [Full Text - PDF] [Purchase Article]

A SPECIAL SECTION

Selected Peer-Reviewed Articles from the 2017 International Conference on Big Data, IoT, and Cloud Computing

(BIC 2017), Jeju, Korea, 22-24 August, 2017

Guest Editors: Gangman Yi and Byoungwook Kim

Adv. Sci. Lett. 23, 12670-12672 (2017)

[Abstract] [Full Text - PDF] [Purchase Article]

\section{RESEARCH ARTICLES}

Construction of Smart Exercise Guide Information System for Supporting Rehabilitation Training Program

Chang Won Jeong, Lypengleang Seang, and Su Chong Joo

Adv. Sci. Lett. 23, 12673-12677 (2017)

[Abstract] [Full Text - PDF] [Purchase Article]

Anti-Plagiarism Systems for Korean Alphabets

Chae-Reen Kim, JinSoo Park, and Doo-Soon Park

Adv. Sci. Lett. 23, 12678-12682 (2017)

[Abstract] [Full Text - PDF] [Purchase Article]

Experimental Results of Zooming Speed and Zooming Pattern for IPTV UI/UX

Samuel Sangkon Lee

Adv. Sci. Lett. 23, 12683-12688 (2017)

[Abstract] [Full Text - PDF] [Purchase Article]

Designing Private LPWAN Gateway

Kwang-il Hwang

Adv. Sci. Lett. 23, 12689-12692 (2017)

[Abstract] [Full Text - PDF] [Purchase Article]

Indexing and Search for a Large Fuzzy Database

Guang-Ho Cha

Adv. Sci. Lett. 23, 12693-12696 (2017)

[Abstract] [Full Text - PDF] [Purchase Article] 
Secret Web Browser Structural Designs for Web Service Capsulation

Changhyun Oh, Mansik Kim, Moon-Seog Jun, and Jungho Kang

Adv. Sci. Lett. 23, 12697-12702 (2017)

[Abstract] [Full Text - PDF] [Purchase Article]

A Study on the Design of the System for Security Risk Assessment of the Works for

Prevention of Money

Laundering at Financial Institutes

PillJung Kim, EunJoo Kim, and JaePyo Park

Adv. Sci. Lett. 23, 12703-12707 (2017)

[Abstract] [Full Text - PDF] [Purchase Article]

A Study on the Derivation of Performance Measurement Items of Public Application Through Survey

PillJung Kim, EunJoo Kim, and JaePyo Park

Adv. Sci. Lett. 23, 12708-12711 (2017)

[Abstract] [Full Text - PDF] [Purchase Article]

Human Action Recognition Using Reproducing Kernel Hilbert Space for Product Manifold of Symmetric

Positive Definite Matrices and K-NN Method

Wanhyun Cho, Sangkyoon Kim, and Soonyoung Park

Adv. Sci. Lett. 23, 12712-12716 (2017)

[Abstract] [Full Text - PDF] [Purchase Article]

A Regression Analysis for the Prediction of the Food Supply in Livestock

Saraswathi Sivamani, Changsun Shin, Jangwoo Park, Kyungryong Cho, and Yongyun Cho

Adv. Sci. Lett. 23, 12717-12720 (2017)

[Abstract] [Full Text - PDF] [Purchase Article]

DRM Market System for Media Service Platform Supporting Multi-DRM in Cloud Environment

Dueckyoun Cho, Seogchan Hwang, and Gunho Jeong

Adv. Sci. Lett. 23, 12721-12724 (2017)

[Abstract] [Full Text - PDF] [Purchase Article]

Suggestion SSL-VPN for Traffic Signal Control System

Hansaem Wi, Chan-Kuk Jang, Jae-Hoon Lee, and Okyeon Yi

Adv. Sci. Lett. 23, 12725-12728 (2017)

[Abstract] [Full Text - PDF] [Purchase Article]

Proposal of Piecewise Key Management Design Considering Capability of Underwater Communication Nodes

Hyunki Kim, Jaehoon Lee, and Okyeon Yi

Adv. Sci. Lett. 23, 12729-12733 (2017)

[Abstract] [Full Text - PDF] [Purchase Article] 
Light Source Difference Image for Retrieving 3D Models

Sungjun Han, Yongbae Kim, and Jongweon Kim

Adv. Sci. Lett. 23, 12734-12737 (2017)

[Abstract] [Full Text - PDF] [Purchase Article]

Proposal for Pricing Adequacy Evaluation of Public Information System Projects in LowestPrice Bidding

Seunghee Kim

Adv. Sci. Lett. 23, 12738-12742 (2017)

[Abstract] [Full Text - PDF] [Purchase Article]

Design of a Low Complexity PHY for Close Proximity Point-to-Point Communication at 60 GHz Band

Jae Seung Lee, Young-Hoon Kim, Hoo Sung Lee, and Moon-Sik Lee

Adv. Sci. Lett. 23, 12743-12747 (2017)

[Abstract] [Full Text - PDF] [Purchase Article]

The Collaboration System of a Drone and Ground Vehicles Using QR Code Detection Myeong-Suk Pak, Jong-Hwan Beck, and Sang-Hoon Kim

Adv. Sci. Lett. 23, 12748-12751 (2017)

[Abstract] [․ㅏll Text - PDF] [urchase Article]

ECDH-Based 3PAKE Protocol for Secure Smart Home Service

Dae-Hwi Lee and Im-Yeong Lee

Adv. Sci. Lett. 23, 12752-12756 (2017)

[Abstract] [Full Text - PDF] [Purchase Article]

WSKE: A Web-Scale Spatial Knowledge Extractor

S. Lee and I. Kim

Adv. Sci. Lett. 23, 12757-12761 (2017)

[Abstract] [Full Text - PDF] [Purchase Article]

Measurement of Sleep Data Using Kinect V2 and Thermovision Camera

Kwi-Bin Seo, Sung-Yeup Kim, and Min Hong

Adv. Sci. Lett. 23, 12762-12768 (2017)

[Abstract] [Full Text - PDF] [Purchase Article]

Customized Recommendation System Based on Rule Matrix in SaaS Aggregation Service Platform

Yun Cui, Myoungjin Kim, Jongjin Jung, Khongmin Kwon, Baul Kim, Ilkyeun Ra, and Hanku Lee Adv. Sci. Lett. 23, 12769-12774 (2017)

[Abstract] [Full Text - PDF] [Purchase Article]

Predicting Flu-Rate Using Big Data Analytics Based on Social Data and Weather Conditions Shikha Verma, Younghee Park, and Mihui Kim

Adv. Sci. Lett. 23, 12775-12779 (2017) 


\section{[Abstract] [Full Text - PDF] [Purchase Article]}

Design and Implementation of NAND Simulator for Bit Error Rate Model Kijin Kim and Seung-Ho Lim Adv. Sci. Lett. 23, 12780-12784 (2017)

[Abstract] [Full Text - PDF] [Purchase Article]

Detection of Malfunction of Gas Sensor Using Principal Component Analysis Ki-Su Yoon, Seoung-Hyeon Lee, Jae-Pil Lee, and Jae-Kwang Lee

Adv. Sci. Lett. 23, 12785-12787 (2017)

[Abstract] [Full Text - PDF] [Purchase Article]

Effective Identification of Essential Proteins Based on Genetic Algorithm Wei Liu, Qiangmei Wu, Jin Wang, and Ling Chen

Adv. Sci. Lett. 23, 12788-12792 (2017)

[Abstract] [Full Text - PDF] [Purchase Article]

An Efficient Partially Blind Signature from Pairing for IoT Environment

Kyung-Soo Lim and Daewon Lee

Adv. Sci. Lett. 23, 12793-12796 (2017)

[Abstract] [Full Text - PDF] [Purchase Article]

A Robust Deep Learning Based Fault Diagnosis of Rotary Machine Bearings Muhammad Sohaib and Jong-Myong Kim

Adv. Sci. Lett. 23, 12797-12801 (2017)

[Abstract] [Full Text - PDF] [Purchase Article]

A Study on User Modeling Based on Consumer Behavior Pattern by Consumption Region Jinah Kim and Nammee Moon

Adv. Sci. Lett. 23, 12802-12806 (2017)

[Abstract] [Full Text - PDF] [Purchase Article]

Towards the Development of Tele-Rehabilitation System Based on Virtual Reality

Environment and Cloud Service

Y. R. Cha, J. Y. Kim, W. H. Gu, S. A. Lee, and B. K. Jung

Adv. Sci. Lett. 23, 12807-12811 (2017)

[Abstract] [Full Text - PDF] [Purchase Article]

A Study on the Performance and Influence of Patent Development Strategy in ICT

Convergence Technology

Using the Big Data

Kyeong-Rae Cho and Su-Been Cho

Adv. Sci. Lett. 23, 12812-12817 (2017)

[Abstract] [Full Text - PDF] [Purchase Article]

Study on Personal Information Leak Detection Based on Machine Learning 
Sangdo Lee, Hanchul Woo, and Yongtae Shin

Adv. Sci. Lett. 23, 12818-12821 (2017)

[Abstract] [Full Text - PDF] [Purchase Article]

System Providing Air Pollution Information Using LED Sculpture

Hyunwoo Lee, Jihoon Yoo, Dongil Shin, and Dongkyoo Shin

Adv. Sci. Lett. 23, 12822-12825 (2017)

[Abstract] [Full Text - PDF] [Purchase Article]

Self-Organizable Flying Agent Control Architecture for Unmanned Aerial Vehicles

Kiwon Yeom

Adv. Sci. Lett. 23, 12826-12830 (2017)

[Abstract] [Full Text - PDF] [Purchase Article]

Anti-Inflammatory Effects for Mobile Electronic Patient Charts Using Numerical Modeling of IoT

Deok Gyu Lee and In-Chul Lee

Adv. Sci. Lett. 23, 12831-12834 (2017)

[Abstract] [Full Text - PDF] [Purchase Article]

Design and Implementation of an Application with File Encryption for Cloud Storage

Minseok Sohn and Yoojae Won

Adv. Sci. Lett. 23, 12835-12838 (2017)

[Abstract] [Full Text - PDF] [Purchase Article]

Table of Contents to Volume 23, Numbers 1-12, 2017

Adv. Sci. Lett. 23, xxxxx-xxxxx (2017)

[Abstract] [Full Text - PDF] [Purchase Article]

Author Index to Volume 23, Numbers 1-12, 2017

Adv. Sci. Lett. 23, xxxxx-Xxxxx (2017)

[Abstract] [Full Text - PDF] [Purchase Article]

Subject Index to Volume 23, Numbers 1-12, 2017

Adv. Sci. Lett. 23, xxxxx-Xxxxx (2017)

[Abstract] [Full Text - PDF] [Purchase Article] 


\section{SCIENCE SChool Counseling Services Information System Optimization in Multi-Level School at Surabaya}

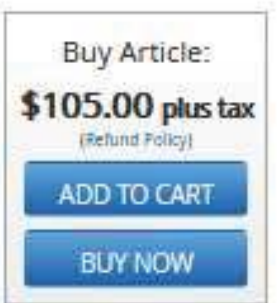

Authors: Limanto, Susana; Andre; Absari, Dhiani Tresna; Setyawan, Sholeh Hadi

Source: Advanced Science Letters, Volume 23, Number 12, December 2017, pp. 11874-11878(5)

Publisher: American Scientific Publishers

DOt: https://doi.org/10.1166/as1.2017.10535

"previous article view table of contents next article >
Abstract References Citations Supplementary Data. Article Media
The success criteria of formal education of a student are not only determined by academic ability, but also by
attitude, interest, and value that is possessed by the student. Therefore, the School Counseling Services (SCS)
becomes more important part of the school, to help students to accept and understand themselves and their
environments. The SCS can also drive the students to self-direct and self-adapt to the demands of their
environments. By providing a good service, SCS can help students to study and reach better achievement in
education, social, and their career related to their interest and their talent. The goal of this research is to develop
a software to optimize process of SC5 used in multi-level school at Surabaya. Software is developed based on
analysis and grand design from previous research. Evaluation of Information System SCS conducted by
distributing survey to all three types of users, which are: Classroom Teacher, Counseling Services Teacher, and
parents. The evaluation results proves that at least $75 \%$ of users agreed that the SCS able to improve teacher
performances, improve capability of collaboration, each user understand its each individual roles, and maintain
communication between different users. Furthermore, SCS IS could be expanded for more better and optimum
service solution. Notification and messaging system between student-parents-teacher could be added to
improve integrity of system, and to minimize redundancy. Academic System and other system such as School
Medical Facilities should be interconnected to improve better services. Deployment planned to be carried out by
executing the old and new systems simultaneously during academic year 2015 -2016 in the scope of
Kindergarten, Grade 1 and 4 Elementary School. Evaluation will be conducted after one year for further
development.

Keywords: Counseling Services; School Information System

Document Type: Research Article

Afriliations: Informatics Engineering Department, University of Surabaya, Raya Kalirungkut, Surabaya 60293, East Java, Indonesia

Publication date: December 1, 2017 


\title{
SCIENCE ₫Computer Utilization as a Balanced Opponent in Dam-
Dam-An
}

Buy Article:

$\$ 105.00$ plus tax

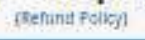

ADD TO CART

BUY NOW

Authors: Purnomo, Setiawan Wibowo; Limanto, Susana; Widiasri, Monica

Source: Advanced Science Letters, Volume 23, Number 12, December 2017, pp. 11889-11891(3)

Publisher. American Scientific Publishers

DOt: https//doi.org/10.1166/asl.2017.10538

\begin{abstract}
<previous article view table of contents next article> $\quad$ ADD TO FAVOURITES

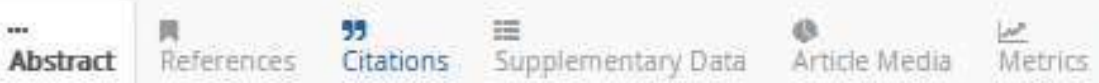

Dam-dam-an is a traditional game played by two players using a board with the size of $8 \times 8$ as a media. Each player gets 16 pieces that can be moved one step forward or leaped over opponent's piece. The goal of this game is to eliminate all of our pieces as soon as possible. It is exciting to have a challenging opponent, yet it is difficult to find a skillful one. A way to solve this problem is using intelligent computer. This paper presents the result of our research about the computer utilization as balanced opponent in dam-dam-an game using AlphaBeta Pruning. Alpha-Beta Pruning is a best-step searching algorithm which works by considering and assessing every possibility while excluding the less useful steps. The implementation is developed using C\# programming language based on Windows Runtime. Some features were added to make this game more exciting, particularly intelligence level selection (easy, medium, and hard), human or computer opponent selection, undo function, pausing menu, save-load the game, and setting the turning time. This game was validated by twenty respondents which were categorized based on their skill. Each respondent played against the computer thrice and the results were recorded. The results showed that the number of winning between the computer and each player are almost the same. It shows that the computer opponent may prove itself to be a challenging opponent for human player.
\end{abstract}

Keywords: Alpha-Beta Pruning; Artificial Intelligence; Dam-Dam-An; Game

Document Type: Research Article

Affiliations: Informatics Engineering Department, University of Surabaya, Surabaya 60293, East Java, indonesia; Raya. Kalirungkut 60293, Surabaya, East Java, Indonesia

Publication date: December 1, 2017 


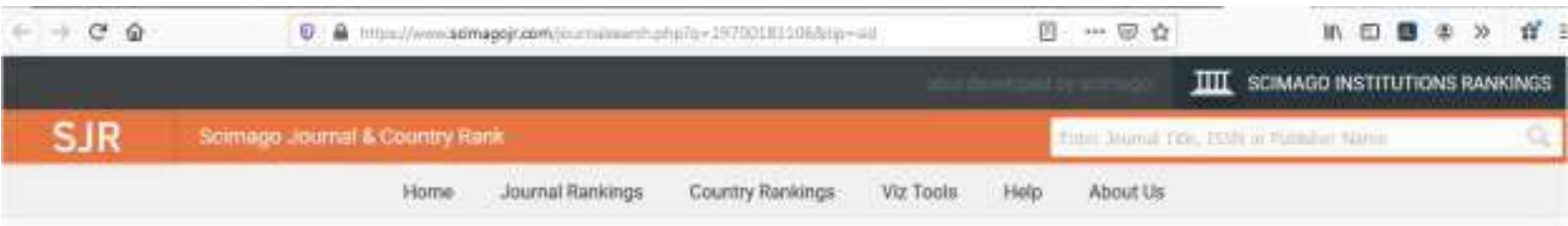

\section{Advanced Science Letters}

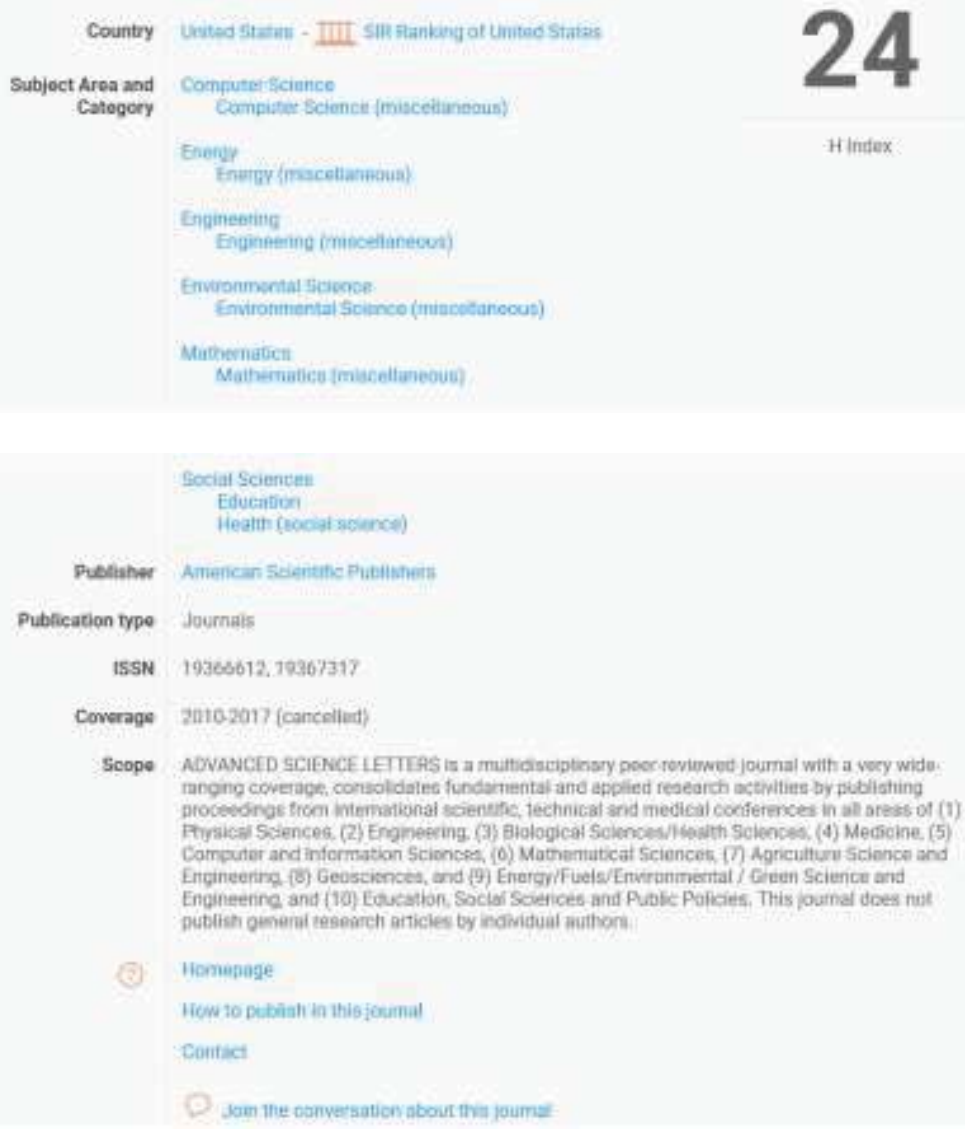

Cunpuer soience imiscrilenetiss

$$
\text { Edration }
$$

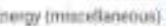
Enginesing (miacettaneusa)

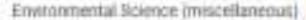

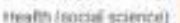
Vathematica imosetlantena)

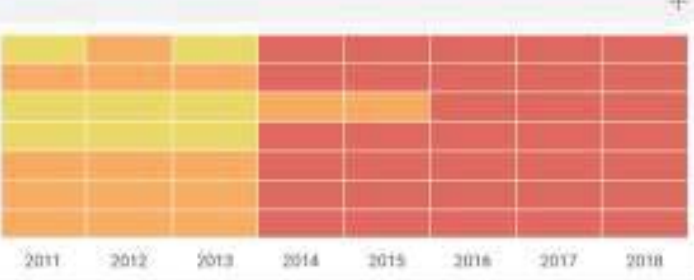



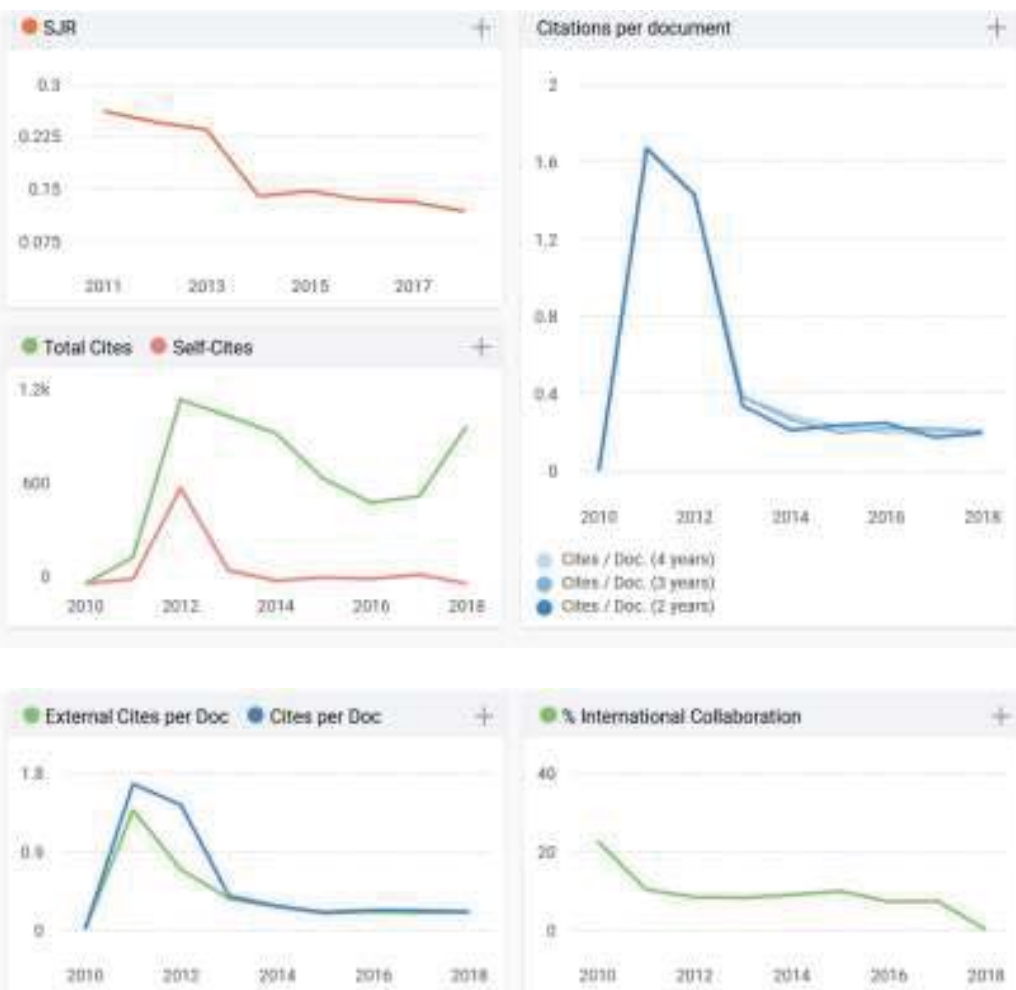

Chable docurrents = Non-itable documents +

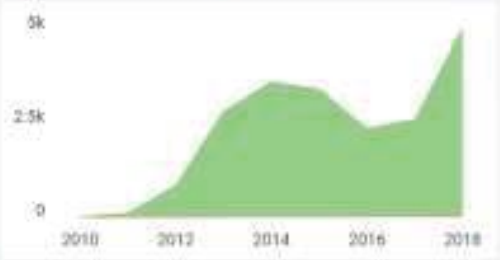

- cited documents e uncited documents + 5i
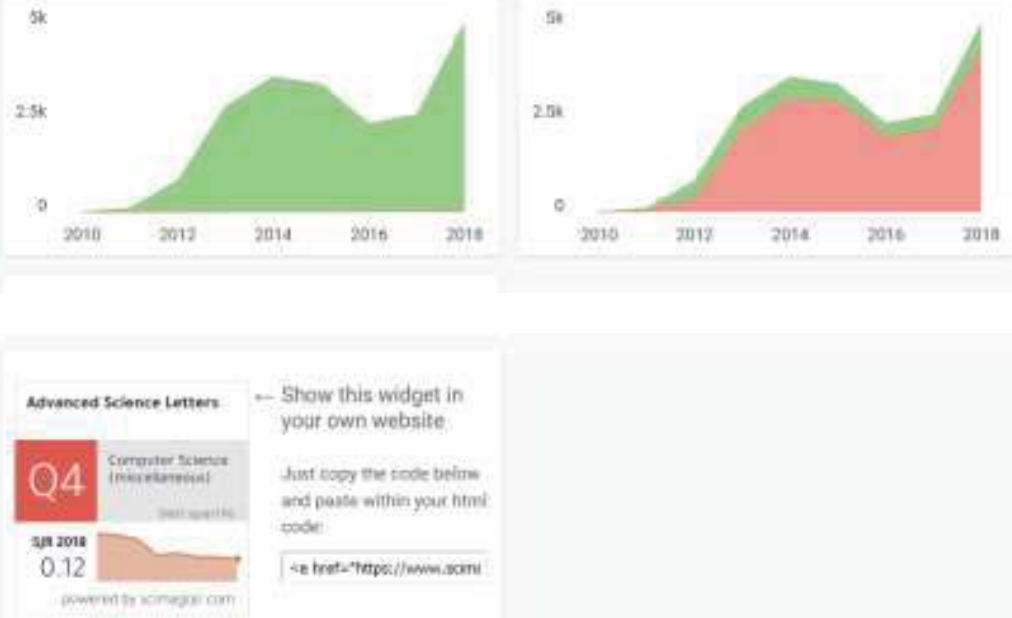